\title{
Interactions of atmospheric gases and aerosols with the monsoon dynamics over the Sudano-Guinean region during AMMA
}

\author{
Adrien Deroubaix ${ }^{1,2}$, Cyrille Flamant ${ }^{2}$, Laurent Menut ${ }^{1}$, Guillaume Siour $^{3}$, Sylvain Mailler ${ }^{1}$, Solène Turquety ${ }^{1}$, \\ Régis Briant $^{1}$, Dmitry Khvorostyanov ${ }^{1}$, and Suzanne Crumeyrolle ${ }^{4}$ \\ ${ }^{1}$ LMD/IPSL, École Polytechnique, Université Paris Saclay, ENS, IPSL Research University, \\ Sorbonne Universités, UPMC Univ Paris 06, CNRS, Palaiseau, France \\ ${ }^{2}$ LATMOS/IPSL, UPMC, Sorbonne Universités, CNRS \& UVSQ, Paris, France \\ ${ }^{3}$ LISA/IPSL, Universités Paris Est Créteil \& Paris Diderot, Créteil, France \\ ${ }^{4}$ LOA, Université Lille 1 Sciences et Technologies, Villeneuve d'Ascq, France
}

Correspondence: Adrien Deroubaix (adrien.deroubaix@1md.polytechnique.fr)

Received: 13 June 2017 - Discussion started: 10 July 2017

Revised: 10 November 2017 - Accepted: 26 November 2017 - Published: 16 January 2018

\begin{abstract}
Carbon monoxide, $\mathrm{CO}$, and fine atmospheric particulate matter, $\mathrm{PM}_{2.5}$, are analyzed over the Guinean Gulf coastal region using the WRF-CHIMERE modeling system and observations during the beginning of the monsoon 2006 (from May to July), corresponding to the Africa Multidisciplinary Monsoon Analysis (AMMA) campaign period.

Along the Guinean Gulf coast, the contribution of longrange pollution transport to $\mathrm{CO}$ or $\mathrm{PM}_{2.5}$ concentrations is important. The contribution of desert dust $\mathrm{PM}_{2.5}$ concentration decreases from $\sim 38 \%$ in May to $\sim 5 \%$ in July. The contribution of biomass burning $\mathrm{PM}_{2.5}$ concentration from Central Africa increases from $\sim 10 \%$ in May to $\sim 52 \%$ in July. The anthropogenic contribution is $\sim 30 \%$ for $\mathrm{CO}$ and $\sim 10 \%$ for $\mathrm{PM}_{2.5}$ during the whole period.

When focusing only on anthropogenic pollution, frequent northward transport events from the coast to the Sahel are associated with periods of low wind and no precipitation. In June, anthropogenic $\mathrm{PM}_{2.5}$ and $\mathrm{CO}$ concentrations are higher than in May or July over the Guinean coastal region. Air mass dynamics concentrate pollutants emitted in the Sahel due to a meridional atmospheric cell. Moreover, a part of the pollution emitted remotely at the coast is transported and accumulated over the Sahel.
\end{abstract}

Focusing the analysis on the period 8-15 June, anthropogenic pollutants emitted along the coastline are exported toward the north especially at the beginning of the night (18:00 to 00:00 UTC) with the establishment of the nocturnal low level jet. Plumes originating from different cities are mixed for some hours at the coast, leading to high pollution concentration, because of specific disturbed meteorological conditions.

\section{Introduction}

The interaction between air pollution and climate in major population centers is a challenging field of research (Baklanov et al., 2016). In the countries of the Guinean Gulf, the population has been growing rapidly during the last decades, accompanied by economic development. Parallel to industrialization, air pollution is increasing without any governmental control (Zhu, 2012).

During the dry season (i.e., November-April), when the harmattan easterly wind is weak, high ozone concentrations and smog are observed over large cities such as Lagos or Cotonou (Marais et al., 2014; Minga et al., 2010). During the wet season (i.e., May-October), the West African monsoon (WAM) wind carries the pollutants northward, and local convective precipitations wash pollutants out of the atmosphere. Two precipitation periods occur over the Guinean Gulf coastal region in April-May and August-September. Between these two periods, the wind coming from the south is predominant (Janicot et al., 2008).

There are various aerosol and gas sources in the Guinean Gulf coastal region during the WAM. Sea salt aerosols are transported in the marine boundary layer, and mineral dust 
aerosols are transported in the Saharan Air Layer (SAL) above the monsoon air (Lafore et al., 2011). Biogenic components are emitted by tropical forests (Reeves et al., 2010) and the urban air pollution from large cities, leading to ozone production (Ancellet et al., 2011; Liousse et al., 2014). In addition, pollutants resulting from incomplete combustion such as carbon monoxide and black carbon particles are coming from the Southern Hemisphere due to biomass burning emissions, and are reaching the Guinean coast in June (Mari et al., 2008; Williams et al., 2010). In situ biomass burning plumes observations have measured high ozone ( $\geq 60 \mathrm{ppb}$ at $700 \mathrm{hPa}$ ) and carbon monoxide ( $\geq 200 \mathrm{ppb}$ at $700 \mathrm{hPa}$ ) concentrations (Sauvage et al., 2005; Mari et al., 2011).

In Nigeria, Akeredolu (1989) listed the different sources of particle loading: biomass burning (31.7\%), fugitive dust from roads $(29.1 \%)$, fuel wood burning $(21.3 \%)$, harmattan dust $(13.8 \%)$, solid waste incineration $(2.1 \%)$, stationary sources $(1.6 \%)$, automobile exhaust lead $(0.2 \%)$ and gas flares $(0.1 \%)$. Since the 1990 s, natural pollution from desert dust and biomass burning has remained important (Mari et al., 2011; Haywood et al., 2008). However, the economic growth over the region drives up anthropogenic emissions. There are increases in industries, including gas flaring (Asuoha and Osu, 2015); local fuel-wood burning for stoves; and traffic (Liousse et al., 2010; Hadji et al., 2012; Liousse et al., 2014). Moreover, the increase in two-wheel vehicles, using very poor quality fuel is suspected to quickly worsen air quality (Ndoke and Jimoh, 2005; Assamoi and Liousse, 2010).

All air quality monitoring studies have shown that the outdoor WHO air quality guidelines (i.e., threshold concentrations) are largely exceeded. These thresholds are $35 \mathrm{ppm}$ for $1 \mathrm{~h}$ and $9 \mathrm{ppm}$ for $8 \mathrm{~h}$ exposure for $\mathrm{CO}$, and $10 \mu \mathrm{g} \mathrm{m}^{-3}$ annual mean and $25 \mu \mathrm{g} \mathrm{m}^{-3}$ for $24 \mathrm{~h}$ mean for $\mathrm{PM}_{2.5}$. For instance, in April 1993, Baumbach et al. (1995) have measured very high levels of $\mathrm{CO}$ (up to $10 \mathrm{ppm}$, measured close to high traffic road) and total particulate matter (up to $200 \mu \mathrm{g} \mathrm{m}^{-3}$ ) based on half-hour averages in Lagos (Nigeria). In Accra (Ghana), Dionisio et al. (2010) have measured $\mathrm{PM}_{2.5}$ up to $200 \mu \mathrm{g} \mathrm{m}^{-3}$ (based on $1 \mathrm{~min}$ averages) in streets polluted by wood stoves, heavy traffic and trash burning. In Ouagadougou (Burkina Faso) $\mathrm{PM}_{2.5}$ observations (based on daily averages) reach $164 \mu_{\mathrm{g} \mathrm{m}^{-3}}$ (Boman et al., 2009) and CO concentration measured in traffic frequently exceed all World Health Organization (WHO) guidelines (Lindén et al., 2008).

The health impact of such air pollution is expected to be high and to increase further without any specific emission regulation (Lindén et al., 2012). It is therefore important to gain a better understanding of pollutant emissions and transport in West Africa. All these results have highlighted the high level of pollution in large cities, also affecting remote places. However, there is no continuous air quality monitoring in West Africa, so existing studies are focused on local scales, short time periods, and few pollutants.
Several observation campaigns have been dedicated to the WAM, notably the Africa Multidisciplinary Monsoon Analysis (AMMA), which was the first international program started to improve our knowledge on all aspects of the WAM (Redelsperger et al., 2006). WAM modeling has made progress; however, the Guinean Gulf coastal region is challenging to model because of the complex land-seaatmosphere interactions.

Along the coastline, there are several atmospheric cells acting on different scales. The diurnal cycle of the landsea breeze occurs at a local scale (a few kilometers). During the day, surface wind is linked with convection within the boundary layer, while at night there is the formation of the nocturnal low-level jet (NLLJ) in response to the daily deep convection activity (Parker et al., 2005). At a regional scale (a few hundred kilometers), the monsoon wind from the south meets the harmattan wind from the north, forming the Intertropical Discontinuity at ground level (Flamant et al., 2007; Cuesta et al., 2009; Karam et al., 2009; Pospichal et al., 2010), and leading to a complex vertical structure (Haywood et al., 2008; Lafore et al., 2011). Between these two scales, an additional meridional atmospheric cell is suspected in the low atmosphere, enhancing convergence at the coast (LeducLeballeur et al., 2013). This cell results from a gradient of wind speed due to the meridional gradient of sea surface temperature (de Coëtlogon et al., 2014). The recent research program "Dynamics-aerosol-chemistry-cloud interactions in West Africa program" (DACCIWA) has been dedicated to the study of land-sea-atmosphere interactions in West Africa. It will contribute to understanding changes in the atmospheric composition due to increasing in emissions over a rapidly growing region, as well as to the development of the next generation of accurate models to forecast weather and pollution in southern West Africa (Knippertz et al., 2015).

This article focuses on transport of pollutants over the Guinean Gulf coastal region, in particular on carbon monoxide and particulate matter with an aerodynamic diameter $D_{\mathrm{p}}<2.5 \mu \mathrm{m}$ (CO and $\mathrm{PM}_{2.5}$ hereafter), which both have a detrimental impact on health (Lelieveld et al., 2015). The scientific questions addressed in this work are the following:

- What is the relative contribution of long-range transported and locally emitted pollutants to surface concentrations from the Guinean Gulf to the Sahel?

- What is the impact of meridional atmospheric cells on the transport of pollutants emitted from large coastal cities?

The pollution patterns are analyzed during the 2006 AMMA period using several observational datasets in combination with numerical simulations of the meteorology as well as of the aerosol-gas chemistry and transport presented in Sect. 2. Section 3 presents the main spatial and temporal patterns over the Sudano-Guinean region of the AMMA study case. Section 4 analyzes the anthropogenic pollution 
from the coast to the Sahel. Section 5 focuses on the analysis of the coastal dynamics and pollution transport. Section 6 focuses on specific study cases. Conclusions and perspectives are given in Sect. 7.

\section{Weather-pollution modeling configuration}

The modeling analysis was performed using the Weather Research and Forecasting (WRF) model for the meteorological fields, which drives the CHIMERE model for the gaseous and particulate species concentrations. Two nested geographical domains are defined: a continental one to take into account remote sources and long-range transport from the Mediterranean sea to the Tropic of Capricorn $\left(27^{\circ} \mathrm{S}\right.$ to $44^{\circ} \mathrm{N}, 38^{\circ} \mathrm{W}$ to $47^{\circ} \mathrm{E}$ ) and a regional one, centered on the Guinean Gulf ( 1 to $20^{\circ} \mathrm{N}, 23^{\circ} \mathrm{W}$ to $17^{\circ} \mathrm{E}$ ). The WRF and CHIMERE models are run offline on the same horizontal grids for the continental and regional domains. The simulated time period is April to July 2006, including a 1-month spin-up. The spin-up time aims at ensuring that all pollutants emitted outside of the modeled domain are present in the domain (depending on the wind speed and direction) since the first modeled hour.

\subsection{Meteorological fields with the WRF model}

The meteorological variables are modeled with the regional non-hydrostatic WRF model (version 3.7.1) presented by Skamarock and Klemp (2008). The continental domain has a constant horizontal resolution of $60 \mathrm{~km} \times 60 \mathrm{~km}$, and the regional domain has a constant horizontal resolution of $20 \mathrm{~km} \times 20 \mathrm{~km}$, both with 32 vertical levels from the surface to $50 \mathrm{hPa}$. We use a two-way nesting with the WRF model.

The global meteorological fields are taken from the US Global Forecast System produced by the National Center for Environmental Prediction. It is read and interpolated hourly by WRF using low-frequency spectral nudging above the planetary boundary layer (PBL) in order to enable the PBL variability to be resolved by WRF (von Storch et al., 2000). We followed the recommendations of Flaounas et al. (2010, 2011) to configure the convection and planetary boundary layer schemes with a setup optimized for the 2006 WAM, especially for the meridional gradient of temperature and the low level circulation.

The Single Moment-6 class microphysics scheme (WSM6) is used allowing for mixed-phase processes suitable for high resolution simulations (Hong and Lim, 2006). Li et al. (2015) have shown that WAM precipitation patterns are very sensitive to the radiation scheme, and the most realistic patterns were obtained with the Rapid Radiative Transfer Model for General Circulation Models (RRTMG) with the Monte-Carlo Independent Column Approximation (McICA) method of random cloud overlap from Mlawer et al. (1997). The planetary boundary layer physics are computed using the Yonsei University scheme (Hong et al., 2006). The cumulus parametrization used is the ensemble Grell-Dévényi scheme, as Crétat and Pohl (2012) have shown that internal variability is much larger with the Kain-Fritsch scheme than with the Grell-Dévényi scheme at the seasonal, intra-seasonal, and daily time scales, and from the regional to the local (grid point) spatial scales. The surface layer scheme is based on Monin-Obukhov with a Carslon-Boland viscous sub-layer. The surface physics are calculated using the "Noah" Land Surface Model scheme with four soil temperatures and moisture layers (Ek et al., 2003).

\subsection{Chemistry transport with the CHIMERE model}

CHIMERE is a regional chemistry-transport model (version 2017), fully described in Menut et al. (2013) and Mailler et al. (2017). The CHIMERE model has previously been used over the AMMA observation period, but only dust aerosols were modeled (Schmechtig et al., 2011; Menut et al., 2009). In this study, all important gas and aerosol sources are included (anthropogenic, biogenic, mineral dust, sea salt and biomass burning). The 32 vertical levels of the WRF model are projected on the 20 levels for CHIMERE from the surface to $200 \mathrm{hPa}$. We use a one-way nesting with the CHIMERE model.

The anthropogenic emissions are estimated by the EDGAR Team using the HTAP v2 (Hemispheric Transport of Air Pollution) annual totals for the year 2010, using inventories based on the MICS-Asia, EPA-US/Canada and TNO databases (available at http://edgar.jrc.ec.europa. eu/htap_v2). Figure 1 presents the anthropogenic PM and $\mathrm{CO}$ emissions over the regional domain and the CotonouNiamey meridional transect used for the analysis in the next sections, defined in longitude $\lambda=2$ to $3^{\circ} \mathrm{E}$ and in latitude $\phi=1$ to $19^{\circ} \mathrm{N}$.

Biomass burning emissions from Central Africa are of primary importance to simulate West African pollution (Giglio et al., 2006). This is achieved using the APIFLAME model (Turquety et al., 2014), which estimates aerosols and chemical species emissions produced by biomass burning. Since the incomplete combustion is both included in anthropogenic inventories (local urban burning) and forests biomass burning inventories, the simulation was designed to split these two parts.

Biogenic emissions are calculated using the MEGAN emissions scheme (Guenther et al., 2006). The mineral dust sources are obtained using the GARLAP (Global Aeolian Roughness Lengths from ASCAT and PARASOL) new global soil and surface dataset made from satellite-derived aeolian roughness lengths with a $6 \mathrm{~km}$ spatial resolution, as detailed in Mailler et al. (2017).

The top and lateral boundary conditions are driven by LMDZ-INCA for aerosols and chemical species (Folberth et al., 2006). The time step is set to $10 \mathrm{~min}$ for the physical 


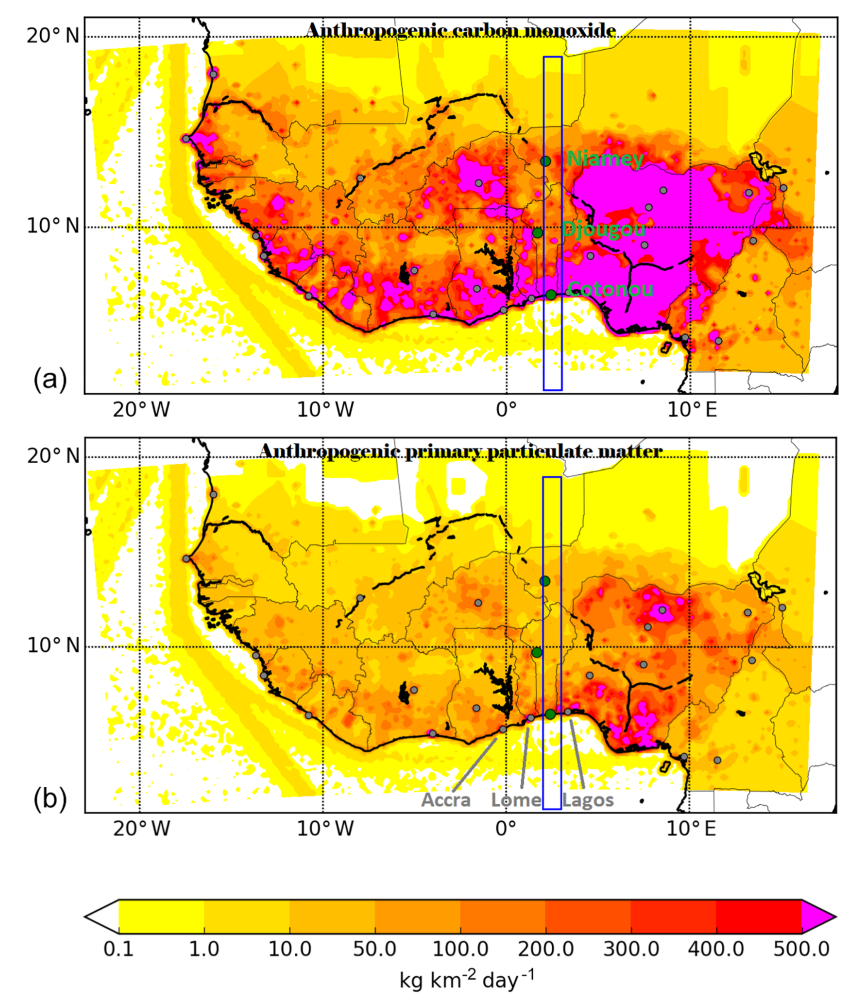

Figure 1. Anthropogenic carbon monoxide (a) and primary particulate matter (b) surface emission fluxes in $\mathrm{kg} \mathrm{km}^{-2} \mathrm{day}^{-1}$ averaged over the 3-month period. The gray dots are the major cities and the three green dots are the locations studied from the south to the north: Cotonou (Benin), Djougou (Benin), Niamey (Niger). The blue box represents the Cotonou (Benin)-Niamey (Niger) meridional transect studied (longitude $\lambda=2^{\circ}$ to $3^{\circ} \mathrm{E}$, latitude $\phi=1$ to $19^{\circ} \mathrm{N}$ ).

processes and $5 \mathrm{~min}$ for the chemistry, which could change depending on the Courant-Friedrichs-Lewy condition. It is also possible to release gaseous or particulate atmospheric tracers, which is a powerful tool to analyze the pollution patterns.

Bessagnet et al. (2004) described the calculation of gaseous species in the MELCHIOR-2 (reduced) scheme and the aerosol scheme, which takes into account species such as sulphate, nitrate, ammonium, primary organic matter (POM) and elemental carbon (EC), secondary organic aerosols (SOA), sea salt, dust and water. All aerosols are represented using $10 \mathrm{bins}$, from $40 \mathrm{~nm}$ to $40 \mu \mathrm{m}$ in diameter. Their life cycle is fully represented with emission, transport, chemistry and deposition (wet and dry).

Menut et al. (2016) have detailed and analyzed aerosol speciation and size distribution in the CHIMERE model during the summer 2013 over Europe and Africa using the AERONET network for aerosol optical depth (AOD) and EMEP network for PM concentrations. For the AOD calculation, the aerosol optical scheme in the CHIMERE model considers mixed aerosols following the "core-shell" hypoth- esis detailed in Péré et al. (2009) and evaluated in Péré et al. (2010).

In order to quantify the $\mathrm{PM}_{2.5}$ source apportionment, we assume that it is possible to split aerosols in different families depending on the sources because their chemical compositions are different: mineral, biogenic, salt and anthropogenic. Given that anthropogenic and biomass burning aerosols have similar compositions, we have done two simulations with and without biomass burning emissions to split their contributions. The gas-phase chemical scheme for SOA formation explained in Bessagnet et al. (2010) takes into account three anthropogenic and three biogenic hydrophilic species, three hydrophobic species with different saturations, and two surrogate compounds for the isoprene oxidation products.

The source apportionment has been determined for $\mathrm{CO}$ considering three main contributors (anthropogenic sources, biomass burning sources and long-range transport). Consequently, three simulations have been done: one without any emission source in the domain for the background concentration, one with the anthropogenic emission only, and a last one with the anthropogenic and biomass burning emissions. The oxidation of volatile organic carbon gases (VOCs), which leads to CO formation is also taken into account in the anthropogenic sources. However, the amount of VOCs is low; for instance, in BAe-146 measurements VOC concentration are lower than $10 \mathrm{ppb}$ (e.g. Capes et al., 2009; Ancellet et al., 2011). Thus CO produced by VOCs oxidation is low (a few $\mathrm{ppb})$.

\section{Temporal variability from May to July 2006}

In this section, we analyze the temporal variability of precipitation, gas and aerosols during the whole AMMA-SOP1 period (Redelsperger et al., 2006). First, the precipitation regimes are identified using Hovmöller diagrams. Second, AERONET surface stations data are used to quantify the 3month variability of the AOD. Finally, the relative contribution to gases and aerosols from several sources is quantified using both airborne observations and modeling. The two last points focus on three locations: Cotonou (Benin), Djougou (Benin) and Niamey (Niger), which are representative of locations under the combined influence of mineral dust, anthropogenic pollution, biogenic and biomass burning components.

\subsection{Precipitation patterns}

During this period, the precipitation location and rate will play a crucial role for the modeled surface $\mathrm{PM}_{2.5}$ concentrations. As a validation for this variable, the methodology of Flaounas et al. (2010) is used: precipitation rates are averaged between $8.5^{\circ} \mathrm{W}$ and $8.5^{\circ} \mathrm{E}$. Day-to-day variability is smoothed by applying a moving average of \pm 2 days. Figure 2 is directly comparable to the Flaounas et al. (2010) study us- 


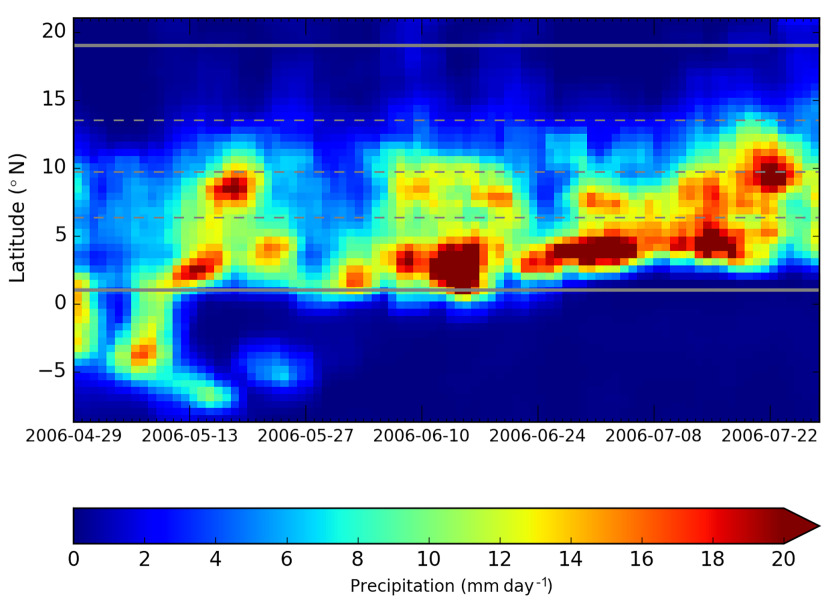

Figure 2. Time-latitude average (Hovmöller) of precipitation $\left(\mathrm{mm} \mathrm{day}^{-1}\right)$. Precipitation is averaged between $8.5^{\circ} \mathrm{W}$ and $8.5^{\circ} \mathrm{E}$ in longitude. Day-to-day variability is eliminated by applying a moving average of \pm 2 days. Due to the longitudinal average, the coastline is between 5 and $6^{\circ} \mathrm{N}$. The two gray lines show the latitudinal extend of the regional model domain. The three dash gray lines represent the latitudes of the three locations studied (Cotonou, Djougou and Niamey).

ing the same period and averaged region. In May and June, observed and modeled precipitations occur mainly over the ocean (below $5^{\circ} \mathrm{N}$ ). From late June on, the main precipitation areas move over the continent (above $5^{\circ} \mathrm{N}$ ) and reach the Sahel (at about $13^{\circ} \mathrm{N}$ ). Figure 2 shows that the modeled precipitation spatial patterns are in good agreement with the two satellite observations (TRMM and GPCP) presented in their study (see Fig. 3 of Flaounas et al., 2010).

The WAM is driven by the sea surface temperature decreases over the Gulf of Guinea and over the Sahara, a low thermal pressure system appears called the Saharan heat low (Lafore et al., 2011). The temperature gradient between the sea and the Sahara allows the monsoon system to progress inland reaching the Sahara in July (Hall and Peyrillé, 2006; Lavaysse et al., 2009). The monsoon progression to the north is not linear due to the complex sea-land-atmosphere interactions (Fig. 2). Two jumps are modeled at the end of May and at the beginning of June. Precipitation is associated with large-scale squall lines, creating mesoscale convective systems (MCSs) moving westward (Hall and Peyrillé, 2006).

The meteorological simulation reproduces the two changes of the main precipitation area that have been previously identified from climatological averages: the "preonset" (i.e., end of May), when the main precipitation area associated with the Intertropical Convergence Zone (ITCZ) located at the Equator moves close to the coast (Sultan and Janicot, 2000; Sultan et al., 2003; Sultan and Janicot, 2003), and the "onset" (i.e., at the beginning of July), when the main precipitation area reaches the Sahel (Janicot et al., 2008). For these dates, simulated precipitation matches very well with
AMMA observations. In 2006, the monsoon onset occurred on the 10 July with a 10-day delay compared to its climatological date, which is 24 June with a standard deviation of 8 days over the period 1968-2005 according to Janicot et al. (2008). Thus, three periods could be defined: before "preonset" (in May), between "pre-onset" and onset (in June), and after onset (in July).

\subsection{Meridional aerosol content}

In our studied region, surface aerosol concentrations in the cities are affected by several contributions. In addition to local emission, cities may be strongly impacted by biomass burning transported from Central Africa (Mari et al., 2008; Williams et al., 2010), or by mineral dust transported from Sahara (Flamant et al., 2009).

The modeled daytime AOD and Ångström exponent are compared to observations from the AERONET network (Holben et al., 1998), available at https://aeronet.gsfc.nasa. gov. From the daily AERONET level-2 measurements of AERONET-AOD (at $440 \mathrm{~nm}$ ) and the Ångström exponent $(440-870 \mathrm{~nm})$, AERONET-AOD is calculated (at $550 \mathrm{~nm}$ ) based on the Ångström law. A spatial bilinear interpolation of the model outputs is performed at the station location.

Two AERONET stations are located close to the meridional transect studied (Fig. 1): Banizoumbou $\left(13.5^{\circ} \mathrm{N}\right.$, $2.1^{\circ} \mathrm{E}$ ) in the suburb of Niamey in Niger, and Djougou in Benin $\left(9.7^{\circ} \mathrm{N}, 1.6^{\circ} \mathrm{E}\right)$ north of the heavily urbanized areas around Cotonou. We compare a simulation made with and without biomass burning emission (with/without BB), presented in Fig. 3.

There are two important events of coarse particles recorded at both sites, associated with a low Ångström exponent (i.e., Ångström exponent lower than 0.5 as in Ogunjobi et al., 2008) and AOD greater than 1, between 13 and 14 May and between 10 and 13 June. The model captures the magnitude of these large-scale dust events. During the studied period, the events of coarse particles are well reproduced (high or moderate AOD is generally associated with a low Ångström exponent). There is an increase in the Ångström exponent, i.e., fine particles over the period, which is well reproduced by the model. Frequent fine-aerosol events (high Ångström exponent) have been monitored corresponding to low or moderate AOD, which are partially captured by the model.

The addition of the biomass burning emissions lead to an important plume of gas and aerosols reaching the Guinean Gulf in June. Modeled AOD with biomass burning emissions are well in the range of the observations but the variability is not captured. In May, the aerosol content is mostly composed of coarse particles (Ångström exponent about 0.2), in June of a fine-coarse mixture of particles (about 0.5), and in July of finer particles, especially at Djougou (Ångström exponent about 0.8 ). The model is able to reproduce this increase in the Ångström exponent, which suggests an aerosol 

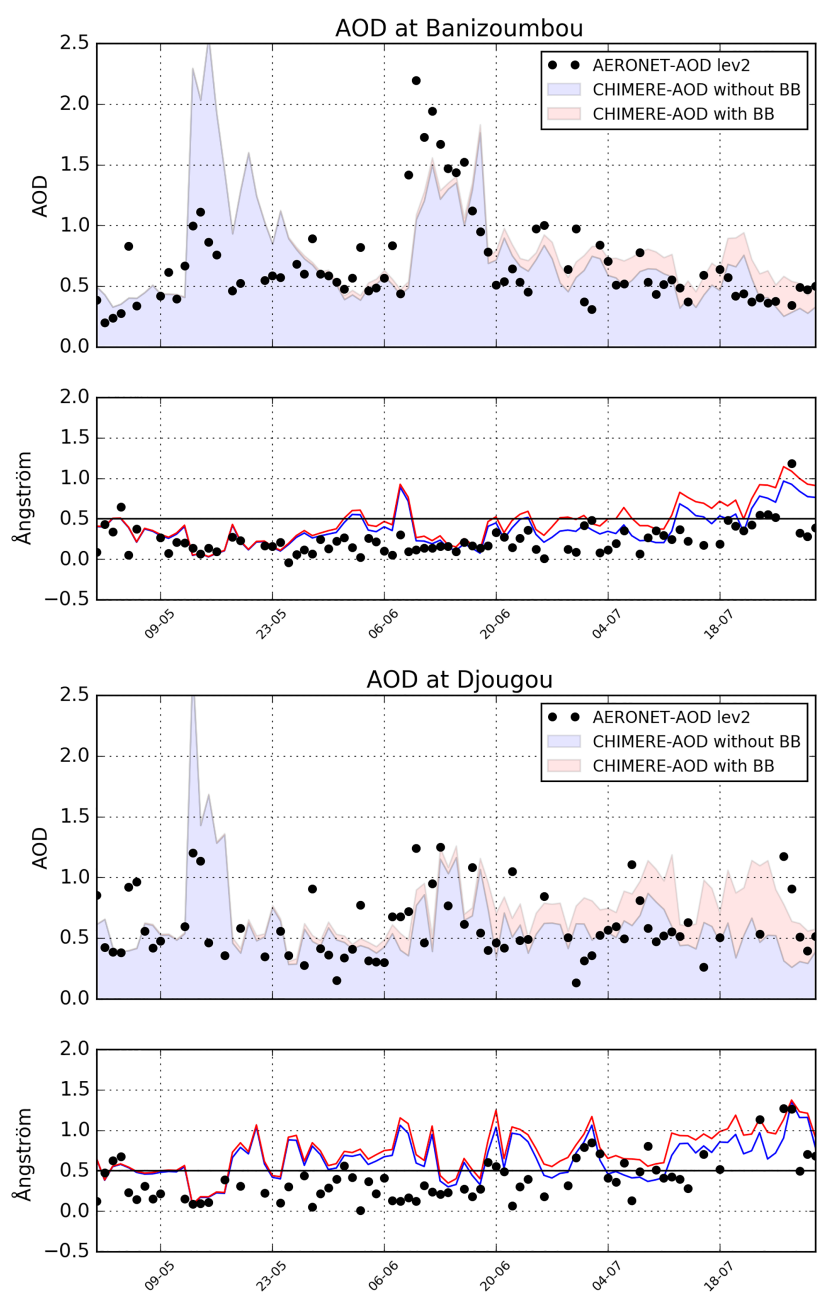

Figure 3. Observed daily averages of AERONET level 2 AOD and Ångström exponent (black dots) at Djougou (Benin) and Banizoumbou compared to the modeled time series with a splitting to extract the relative contribution between without biomass burning emissions (including anthropogenic, biogenic, sea salt and mineral dust; all four in blue) and with biomass burning emissions (in red).

origin transition, from a period dominated by desert dust to a period of fine particles which could be local urban and/or biomass burning pollution from the south.

\subsection{Meridional aerosol and gas concentrations}

In this section, the modeled $\mathrm{CO}$ and $\mathrm{PM}_{2.5}$ concentrations are compared to aircraft observations collected during the AMMA campaign (Sect. 3.3.1), available on the AMMA database (http://baobab.sedoo.fr/AMMA/)(although other datasets exist). Then, the different contributions of the pollution sources are analyzed from the modeled concentrations at the three studied sites (Sect. 3.3.2).

\subsubsection{Airborne observations}

We are studying two flights conducted along a meridional transect between Cotonou and Niamey on 13 and 14 June 2006 as part of a "north-south land-atmosphere-ocean interaction" survey mission. During these 2 days, the WAM dynamics over the area were perturbed by the presence of a MCS. It developed over the Jos Plateau (Nigeria) around 16:00 UTC, reaching the Benin-Nigeria border at 20:00 UTC and moving southwestward across Benin overnight and into central Ghana, as already described in Flamant et al. (2009) and (Crumeyrolle et al., 2011). The model reproduces the location of this MCS but earlier than in the observations, i.e., reaching the Benin-Nigeria border at 10:00 UTC (Fig. 4). The MCS interacts with the dust layer coming from the Sahara (especially from the Bodélé depression), changing the dust load and vertical distribution over Benin and Niger. Associated with subsidence in the wake of the MCS, there is a lowering of the dust layer height (Flamant et al., 2009).

Modeled $\mathrm{CO}$ and $\mathrm{PM}_{2.5}$ concentrations are compared to aircraft measurements performed onboard the ATR-42 aircraft (with PCASP instrument for PM), which have been averaged at a $2 \mathrm{~min}$ time step. The modeled values are interpolated along the aircraft trajectories, in time between the two closest modeled hourly outputs, and vertically between the two closest model vertical levels and horizontally with a bilinear interpolation. For the two flights (13 July in the morning from Niamey to Cotonou, and 14 July in the afternoon from Cotonou to Niamey), Table 1 presents modeled and observed mean spatial values and ranges of $\mathrm{CO}$ and $\mathrm{PM}_{2.5}$ concentrations in the PBL (altitude lower than $1000 \mathrm{~m})$ over three regions: the coastal region, including Cotonou $\left(6.3-9.0^{\circ} \mathrm{N}\right)$; the Sudano-Guinean region, including Djougou $\left(9.0-11.0^{\circ} \mathrm{N}\right)$; and the Sudano-Sahelian region, including Niamey $\left(11.0-13.5^{\circ} \mathrm{N}\right)$.

For CO concentration, on 13 June, there is no clear gradient over the three regions but rather a constant concentration of about $170 \mathrm{ppb}$. On 14 June, we can noticed a gradient from the coast (200 ppb) to the Sahel (167 ppb). For both days, the model predicts a gradient with the highest concentration over the Sahel. Over the coastal region, the observed CO concentration range is similar for the two flights (between 147 and $222 \mathrm{ppb}$ ), which is in good agreement with the modeled range (between 175 and $240 \mathrm{ppb}$ ). Over the Sudano-Guinean region, the observed range of variation is $161-182 \mathrm{ppb}$ prior to the MCS (13 June), and it increases to $153-233 \mathrm{ppb}$ after the MCS (14 June). The model is able to capture the larger variability on 14 June (205-247 ppb compared to 218$245 \mathrm{ppb}$ on 13 June). Over the Sudano-Sahelian region, the observed variability of $\mathrm{CO}$ concentration is also larger on 14 June (146-200 ppb) than on 13 June (149-174 ppb). This behavior is not reproduced in modeled concentrations. There is an overestimation of the modeled CO concentration (positive bias of $\sim 20 \mathrm{ppb}$ ) for 13 and 14 June. 
Table 1. Range of 2 min average modeled and observed concentrations of $\mathrm{CO}(\mathrm{ppb})$ and $\mathrm{PM}_{2.5}\left(\mu \mathrm{g} \mathrm{m}^{-3}\right.$ ) in the PBL (altitude lower than $1000 \mathrm{~m})$ over three regions: coastal region $\left(6.3-9.0^{\circ} \mathrm{N}\right)$, Sudano-Guinean region $\left(9.0-11.0^{\circ} \mathrm{N}\right)$, and Sudano-Sahelian region $\left(11.0-13.5^{\circ} \mathrm{N}\right)$.

\begin{tabular}{|c|c|c|c|c|c|c|c|c|c|}
\hline Pollutants obs/mod & \multicolumn{3}{|c|}{ Coastal region } & \multicolumn{3}{|c|}{ Sudano-Guinean region } & \multicolumn{3}{|c|}{ Sudano-Sahelian region } \\
\hline \multicolumn{10}{|c|}{ Aircraft observations of 13 June 2006 from 10:00 to 13:00 UTC } \\
\hline & Mean & Min & $\operatorname{Max} \mid$ & Mean & Min & Max & Mean & Min & Max \\
\hline CO CHIMERE (ppb) & 207.24 & 174.90 & 233.03 & 231.52 & 217.50 & 244.54 & 243.88 & 212.25 & 275.76 \\
\hline $\mathrm{CO}$ aircraft (ppb) & 172.78 & 146.78 & 209.21 & 172.51 & 161.43 & 182.14 & 159.26 & 148.70 & 174.24 \\
\hline $\mathrm{PM}_{2.5}$ CHIMERE $\left(\mu \mathrm{g} \mathrm{m}^{-3}\right)$ & 23.95 & 19.26 & 26.01 & 28.96 & 25.46 & 33.87 & 55.15 & 35.18 & 79.93 \\
\hline $\mathrm{PM}_{2.5}$ Aircraft $\left(\mu \mathrm{g} \mathrm{m}^{-3}\right)$ & 15.67 & 7.57 & 33.02 & 49.72 & 22.33 & 77.88 & 55.81 & 34.22 & 72.20 \\
\hline \multicolumn{10}{|c|}{ Aircraft observations of 14 June 2006 from 13:00 to 16:00 UTC } \\
\hline & Mean & Min & $\operatorname{Max} \mid$ & Mean & Min & $\operatorname{Max}$ & Mean & Min & $\operatorname{Max}$ \\
\hline CO CHIMERE (ppb) & 212.71 & 190.23 & 239.83 & 229.15 & 205.49 & 246.75 & 244.74 & 232.68 & 257.97 \\
\hline $\mathrm{CO}$ aircraft (ppb) & 200.21 & 185.49 & 222.34 & 181.51 & 153.11 & 233.35 & 168.66 & 146.35 & 200.66 \\
\hline $\mathrm{PM}_{2.5}$ CHIMERE $\left(\mu \mathrm{g} \mathrm{m}^{-3}\right)$ & 42.79 & 28.23 & 64.33 & 82.25 & 64.43 & 92.93 & 84.01 & 79.65 & 91.46 \\
\hline $\mathrm{PM}_{2.5}$ aircraft $\left(\mu \mathrm{g} \mathrm{m}^{-3}\right)$ & 39.40 & 37.26 & 42.37 & 39.36 & 23.60 & 59.12 & 92.08 & 50.11 & 138.86 \\
\hline
\end{tabular}

For $\mathrm{PM}_{2.5}$ concentrations, a south-north gradient is expected with the highest concentrations close to the Sahara. There is a clear gradient in the observed $\mathrm{PM}_{2.5}$ concentration mean on 13 June between the coastal region $\left(8 \mu \mathrm{g} \mathrm{m}^{-3}\right)$ and the Sudano-Guinean region $\left(50 \mu \mathrm{g} \mathrm{m}^{-3}\right)$, and almost the same concentration in the Sudano-Guinean and the SudanoSahelian region $\left(56 \mu \mathrm{g} \mathrm{m}^{-3}\right)$. After the MCS, there is no clear gradient but rather the same concentration over the coastal and the Sudano-Guinean regions $\left(39 \mu \mathrm{g} \mathrm{m}^{-3}\right)$. However, there is an important increase in the concentration moving to the Sahel (up to $92 \mu \mathrm{g} \mathrm{m}^{-3}$ ). The variability is increased over the three regions: $37-42 \mu \mathrm{g} \mathrm{m}^{-3}$ for the coastal region, $24-59 \mathrm{\mu g} \mathrm{m}^{-3}$ for the Sudano-Guinean region, and $50-139 \mu \mathrm{g} \mathrm{m}^{-3}$ for the Sudano-Sahelian region. The modeled ranges match the observed ones for both days. The model reproduces a south-north gradient on 13 June, which is well in agreement with the observations. On 14 June, the model predicts the concentration gap between the coastal and the Sudano-Guinean regions (from 43 to $82 \mu \mathrm{g} \mathrm{m}^{-3}$ ), while it was observed between the Sudano-Guinean and the Sahelian regions.

These 2 days correspond to disturbed meteorological conditions, which may not be representative of the typical average concentrations. The model-observation comparison suggests that the MCS occurs later in the observation, which could in turn induce a unrealistic modeled pollution plume (for instance a biomass burning plume) over the SudanoSahelian region and the Sahel. Nevertheless, the orders of magnitude of the $\mathrm{CO}$ and $\mathrm{PM}_{2.5}$ concentrations are good in agreement with observations.

\subsubsection{Monthly modeled pollution source apportionment}

In order to analyze the source apportionment, we consider that the $\mathrm{CO}$ mixing ratio is due to three major contributors long-range transport and anthropogenic and biomass burning sources - and that the $\mathrm{PM}_{2.5}$ mass concentration comes from five major types of pollution source: anthropogenic, biomass burning, mineral dust, biogenic and sea salt (we assume that $\mathrm{PM}_{2.5}$ background concentration is negligible). The relative percentage of each source is presented for $\mathrm{CO}$ in Table 2 and for $\mathrm{PM}_{2.5}$ Table 3 at the three studied locations - Cotonou, Djougou and Niamey - for the whole period and for each month of the simulation.

For the three sites, the average concentrations of surface $\mathrm{CO}$ increase during the whole period. The mean concentrations are very close for the three sites: $221 \mathrm{ppb}$ in Cotonou, $227 \mathrm{ppb}$ in Djougou, and $212 \mathrm{ppb}$ in Niamey. There is a clear increase in CO from May (157-180 ppb) to July (267$280 \mathrm{ppb}$ ). This increase is due to the biomass burning sources from May $(3-10 \%)$ to July (40-49\%), while the anthropogenic and background concentrations are stable during the whole period and for all sites. It seems that the $\mathrm{CO}$ overestimation noticed in the previous section is linked with an overestimation of biomass burning emissions.

$\mathrm{PM}_{2.5}$ concentrations display a south-north gradient of concentrations $\left(30 \mu \mathrm{g} \mathrm{m}^{-3}\right.$ in Cotonou, $38 \mu \mathrm{g} \mathrm{m}^{-3}$ in Djougou, $54 \mu \mathrm{g} \mathrm{m}^{-3}$ in Niamey) on average over the whole period, consistent with the gradient of dust contribution (15\% in Cotonou, $35 \%$ in Djougou, $67 \%$ in Niamey). From May to July and for all sites, the mineral dust contribution is constantly decreasing. On the other hand, the biomass burning contribution increases ( 3 to $19 \mu \mathrm{g} \mathrm{m}^{-3}$ in Cotonou, 1 to $17 \mu \mathrm{g} \mathrm{m}^{-3}$ in Djougou, 0.6 to $11 \mu \mathrm{g} \mathrm{m}^{-3}$ in Niamey), which seems to be overestimated as for $\mathrm{CO}$ concentration. Over the 
Table 2. CO (ppb) average and relative contributions (\%) of each type of pollution source (background, anthropogenic, biomass burning) at Cotonou (Benin), Djougou (Benin) and Niamey (Niger). The time-averaged periods correspond to each month (May, June, July) and to the whole period (from May to July).

\begin{tabular}{|c|c|c|c|c|c|c|c|c|}
\hline $\mathrm{CO}$ & \multicolumn{2}{|c|}{ May-July } & \multicolumn{2}{|c|}{ May } & \multicolumn{2}{|c|}{ June } & \multicolumn{2}{|c|}{ July } \\
\hline \multicolumn{9}{|l|}{ Cotonou (Benin) } \\
\hline Average (ppb) & 221.01 & & 157.25 & & 239.11 & & 267.26 & \\
\hline Background (ppb and \%) & 73.30 & 33.17 & 73.58 & 46.79 & 72.82 & 30.45 & 73.48 & 27.50 \\
\hline Anthropogenic (ppb and \%) & 64.75 & 29.30 & 67.83 & 43.14 & 64.65 & 27.04 & 61.77 & 23.11 \\
\hline Biomass burning (ppb and \%) & 82.96 & 37.54 & 15.84 & 10.07 & 101.64 & 42.51 & 132.00 & 49.39 \\
\hline \multicolumn{9}{|l|}{ Djougou (Benin) } \\
\hline Average (ppb) & 226.78 & & 180.28 & & 240.65 & & 259.85 & \\
\hline Background (ppb and \%) & 75.27 & 33.19 & 77.38 & 42.92 & 75.23 & 31.26 & 73.21 & 28.17 \\
\hline Anthropogenic (ppb and \%) & 80.77 & 35.62 & 93.52 & 51.88 & 89.01 & 36.99 & 60.04 & 23.11 \\
\hline Biomass burning (ppb and \%) & 70.74 & 31.19 & 9.38 & 5.21 & 76.41 & 31.75 & 126.60 & 48.72 \\
\hline \multicolumn{9}{|l|}{ Niamey (Niger) } \\
\hline Average (ppb) & 212.44 & & 171.24 & & 229.26 & & 237.34 & \\
\hline Background (ppb and \%) & 78.95 & 37.16 & 82.72 & 48.30 & 78.69 & 34.32 & 75.42 & 31.78 \\
\hline Anthropogenic (ppb and \%) & 82.54 & 38.85 & 83.92 & 49.01 & 98.24 & 42.85 & 65.96 & 27.79 \\
\hline Biomass burning (ppb and \%) & 50.95 & 23.98 & 4.60 & 2.69 & 52.33 & 22.82 & 95.97 & 40.43 \\
\hline
\end{tabular}

studied area, $\mathrm{PM}_{2.5}$ concentrations are dominated by longrange transport of biomass burning and dust aerosols. Anthropogenic $\mathrm{PM}_{2.5}$ concentrations range from 3 to $5 \mu \mathrm{g} \mathrm{m}^{-3}$, which is about $10 \%$ for the whole period and for the three sites.

In Cotonou, the average concentration of surface $\mathrm{PM}_{2.5}$ increases during the whole period, from 23 to $37 \mu \mathrm{g} \mathrm{m}^{-3}$. This mainly corresponds to the arrival of biomass burning emission products, transported from Central Africa to the Guinean Gulf, with an increase from 11 to $52 \%$ from May to July. However, the mineral dust contribution decreases during the period, from 38 to $5 \%$. The sea salt contribution increases from 3 to $6 \mathrm{ppb}$. During the 3 months, the anthropogenic and biogenic contributions remain stable at about 4 and $6 \mu \mathrm{g} \mathrm{m}^{-3}$, respectively.

In Djougou, the same behavior is observed but with some changes in the absolute values. The relative contribution of mineral dust decreases from 57 to $14 \%$, while the biomass burning contribution increases from 3 to $47 \%$. The anthropogenic contribution is slightly higher in June at about $5 \mu \mathrm{g} \mathrm{m}^{-3}$.

In Niamey, the dust contribution is important for the 3 months. It decreases by a factor 4 , from 61 to $15 \mu \mathrm{g} \mathrm{m}^{-3}$, consistent with observation of $\mathrm{PM}_{10}$ in Banizoumbou in Niger (Marticorena et al., 2010), which is probably due to the reduction of local emission linked with the increase in vegetation cover. The relative contribution of anthropogenic pollution is slightly higher in June at about $5 \mu \mathrm{g} \mathrm{m}^{-3}$.
For $\mathrm{CO}$ or $\mathrm{PM}_{2.5}$ concentrations, the anthropogenic emissions contribute significantly to the total budget $(\sim 30 \%$ for $\mathrm{CO}$ and $\sim 10 \%$ for $\mathrm{PM}_{2.5}$ ). It is therefore important to better understand the daily variability of anthropogenic pollutant transport.

\section{Focus on anthropogenic pollutants from Cotonou to Niamey}

This section focuses on the horizontal variability and vertical structure of anthropogenic pollution. Only the contribution of anthropogenic sources is considered in $\mathrm{PM}_{2.5}$ and $\mathrm{CO}$ concentrations, from now on referred to as anth- $\mathrm{PM}_{2.5}$ and anth-CO.

\subsection{Time-latitude variability at the surface}

\subsection{1 $\mathrm{CO}$ and $\mathrm{PM}_{2.5}$ concentrations}

The Cotonou-Niamey meridional transect includes the two specific cities extensively studied in the framework of the AMMA program: a large coastal city (Cotonou in Benin) and a Sahelian city (Niamey in Niger). To highlight the latitudinal regional transport, modeled concentrations are presented with the same methodology as in the previous section with Hovmöller diagrams, corresponding to time-latitude average of variables (data are smoothed with a 5-day moving average, i.e., \pm 2 days $)$. 
Table 3. $\mathrm{PM}_{2.5}\left(\mu \mathrm{g} \mathrm{m}^{-3}\right)$ average and relative contributions (\%) of type of pollution source (anthropogenic, biomass burning, dust, biogenic, sea salt) at Cotonou (Benin), Djougou (Benin) and Niamey (Niger). The time-averaged periods correspond to each month (May, June July) and to the whole period (from May to July).

\begin{tabular}{|c|c|c|c|c|c|c|c|c|}
\hline $\mathrm{PM}_{2.5}$ & \multicolumn{2}{|c|}{ May-July } & \multicolumn{2}{|c|}{ May } & \multicolumn{2}{|c|}{ June } & \multicolumn{2}{|c|}{ July } \\
\hline \multicolumn{9}{|l|}{ Cotonou (Benin) } \\
\hline Average $\left(\mu \mathrm{g} \mathrm{m}^{-3}\right)$ & 29.62 & & 23.31 & & 28.89 & & 36.64 & \\
\hline Anthropogenic $\left(\mu \mathrm{g} \mathrm{m}^{-3}\right.$ and $\left.\%\right)$ & 3.45 & 11.64 & 3.44 & 14.75 & 3.44 & 11.90 & 3.47 & 9.46 \\
\hline Biomass burning ( $\mu \mathrm{g} \mathrm{m}^{-3}$ and $\%$ ) & 12.02 & 40.58 & 2.54 & 10.89 & 14.38 & 49.79 & 19.21 & 52.44 \\
\hline Dust $\left(\mu \mathrm{g} \mathrm{m}^{-3}\right.$ and $\left.\%\right)$ & 4.35 & 14.68 & 8.89 & 38.15 & 2.34 & 8.10 & 1.74 & 4.76 \\
\hline Biogenic $\left(\mu \mathrm{g} \mathrm{m}^{-3}\right.$ and $\left.\%\right)$ & 6.04 & 20.38 & 5.84 & 25.04 & 5.68 & 19.65 & 6.59 & 17.98 \\
\hline Salt $\left(\mu \mathrm{g} \mathrm{m}^{-3}\right.$ and $\left.\%\right)$ & 3.77 & 12.72 & 2.60 & 11.17 & 3.05 & 10.56 & 5.62 & 15.35 \\
\hline \multicolumn{9}{|l|}{ Djougou (Benin) } \\
\hline Average $\left(\mu \mathrm{g} \mathrm{m}^{-3}\right)$ & 38.25 & & 41.31 & & 37.71 & & 35.70 & \\
\hline Anthropogenic $\left(\mu \mathrm{g} \mathrm{m}^{-3}\right.$ and $\left.\%\right)$ & 4.10 & 10.72 & 4.38 & 10.60 & 4.59 & 12.16 & 3.35 & 9.38 \\
\hline Biomass burning $\left(\mu \mathrm{g} \mathrm{m}^{-3}\right.$ and $\left.\%\right)$ & 9.18 & 23.99 & 1.34 & 3.23 & 9.36 & 24.82 & 16.84 & 47.17 \\
\hline Dust $\left(\mu \mathrm{g} \mathrm{m}^{-3}\right.$ and $\left.\%\right)$ & 13.55 & 35.43 & 23.73 & 57.44 & 12.05 & 31.95 & 4.83 & 13.52 \\
\hline Biogenic $\left(\mu \mathrm{g} \mathrm{m}^{-3}\right.$ and $\left.\%\right)$ & 9.95 & 26.01 & 10.76 & 26.05 & 10.44 & 27.68 & 8.66 & 24.25 \\
\hline Salt $\left(\mu \mathrm{g} \mathrm{m}^{-3}\right.$ and $\left.\%\right)$ & 1.47 & 3.85 & 1.10 & 2.67 & 1.28 & 3.39 & 2.03 & 5.68 \\
\hline \multicolumn{9}{|l|}{ Niamey (Niger) } \\
\hline Average $\left(\mu \mathrm{g} \mathrm{m}^{-3}\right)$ & 53.76 & & 71.59 & & 52.56 & & 37.09 & \\
\hline Anthropogenic $\left(\mu \mathrm{g} \mathrm{m}^{-3}\right.$ and $\left.\%\right)$ & 4.22 & 7.85 & 4.00 & 5.58 & 5.15 & 9.80 & 3.54 & 9.54 \\
\hline Biomass burning ( $\mu \mathrm{g} \mathrm{m}^{-3}$ and $\left.\%\right)$ & 5.73 & 10.66 & 0.56 & 0.78 & 5.47 & 10.41 & 11.15 & 30.06 \\
\hline Dust $\left(\mu \mathrm{g} \mathrm{m}^{-3}\right.$ and $\left.\%\right)$ & 36.86 & 68.57 & 61.02 & 85.24 & 34.34 & 65.35 & 15.14 & 40.83 \\
\hline Biogenic $\left(\mu \mathrm{g} \mathrm{m}^{-3}\right.$ and $\left.\%\right)$ & 6.31 & 11.75 & 5.58 & 7.79 & 7.08 & 13.48 & 6.31 & 17.01 \\
\hline Salt $\left(\mu \mathrm{g} \mathrm{m}^{-3}\right.$ and $\left.\%\right)$ & 0.63 & 1.18 & 0.44 & 0.61 & 0.51 & 0.96 & 0.95 & 2.56 \\
\hline
\end{tabular}

Results are presented in Fig. 5 for anth-CO and anth$\mathrm{PM}_{2.5}$. For the two species, meteorological parameters are superimposed on the concentrations. Precipitation rate contours are defined for events with more than $10 \mathrm{~mm} \mathrm{day}^{-1}$ over the Cotonou-Niamey transect. These are similar but not equivalent patterns to those presented in Sect. 3.1 averaged over the whole of West Africa.

The Intertropical Discontinuity (ITD) is the limit between the northward monsoon wind and the southward harmattan wind (Flamant et al., 2007; Karam et al., 2009). The ITD could be defined as the isocontour of relative humidity (RH) equal to $20 \%$. We can notice that the location of the ITD associated with a sharp gradient in surface anthropogenic concentrations, with a decrease going further north from 100 to $20 \mathrm{ppb}$ for $\mathrm{CO}$, and from 5 to $2 \mu \mathrm{g} \mathrm{m}^{-3}$ for $\mathrm{PM}_{2.5}$.

For anth-CO surface concentrations, high concentrations are continuously modeled from the beginning of May to late June at the coast where Cotonou is located, about $100 \mathrm{ppb}$ around $\phi=6.3^{\circ} \mathrm{N}$. Over the Guinean Gulf, the concentration is low between 20 and $50 \mathrm{ppb}$. The second area with high anth-CO values corresponds to the Sudano-Sahelian region, where concentrations vary between 60 and $100 \mathrm{ppb}$ around $\phi=12^{\circ} \mathrm{N}$. Whereas high concentrations of anth-CO at the coast are clearly related to local emissions, the high concentrations over the Sahel could be due to either transport or local emissions. Over the studied domain, anth-CO surface concentrations evolve between 20 and $120 \mathrm{ppb}$. There are some high modeled surface concentrations in May and in June when rain occurs, such as around 11 June. In July, the variability is mostly consistent with precipitation rates after the onset, suggesting modifications of transport and deposition patterns by the convection associated with large-scale precipitation. Precipitation variability can thus explain only a part of the $\mathrm{CO}$ variability. It is necessary to also investigate the large-scale wind speed and direction.

The same behavior is observed for the surface concentrations of anth-PM $\mathrm{PM}_{2.5}$. The week-to-week variability is greater than for anth-CO, which is probably due to the longer lifetime of CO compared with that of PM (being less chemically active and less prone to settling). $\mathrm{CO}$ is more homogeneously mixed than PM in a large latitudinal area spanning from the coast to latitudes higher than $16^{\circ}$. The temporal variability of surface anth- $\mathrm{PM}_{2.5}$ exhibits a periodicity close to 2 weeks: during the whole modeled period, five higher-concentration 


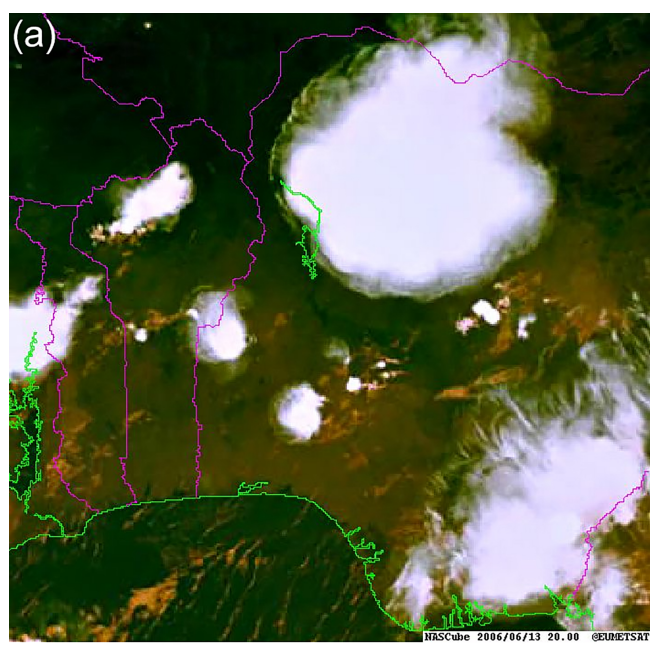

(b)

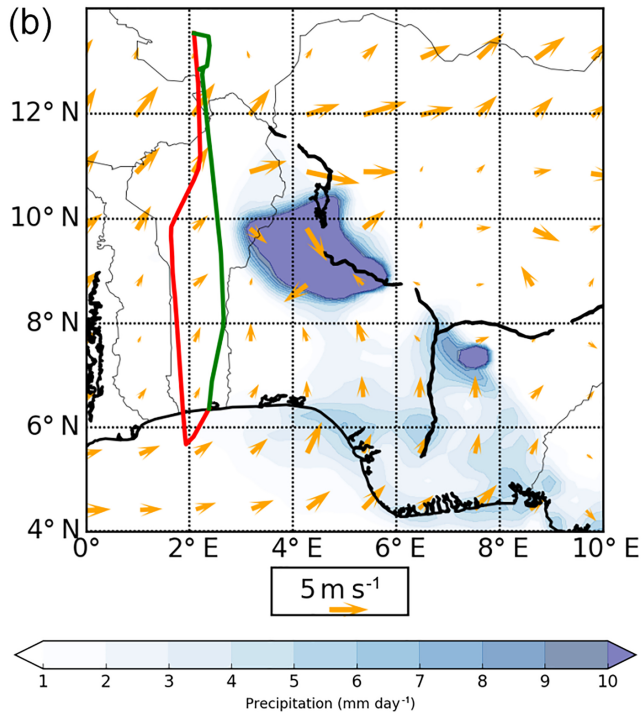

Figure 4. (a) EUMETSAT visible image of the Cotonou area of 13 June 2006 at 20:00 UTC (from NAScube http://nascube.univ-lille1. fr); (b) map of the Cotonou area for 13 June 2006 at 12:00 UTC with wind vectors at $10 \mathrm{~m}$ (orange arrows) and precipitation (blue shading). The two flight trajectories are displayed with the red line for 13 June and with the green line for 14 June.

periods are observed from the coast to $\phi \approx 16^{\circ} \mathrm{N}$. In addition in these latitudinal patterns, local minima are modeled, for instance 20 June. At $\phi=12^{\circ} \mathrm{N}$, there is an area of high concentration which is present over the whole period. This may be related to vertical transport and will be quantified in the next sections. The results show similarities for both two pollutants in terms of time-latitude variability; the next sections will refine the analysis only for anth-PM $\mathrm{PM}_{2.5}$.

\subsubsection{Synoptic wind and pollution}

This section aims at analyzing the anth- $\mathrm{PM}_{2.5}$ concentration temporal variability through the surface wind speed and direction. The previous section has shown that low pollu-
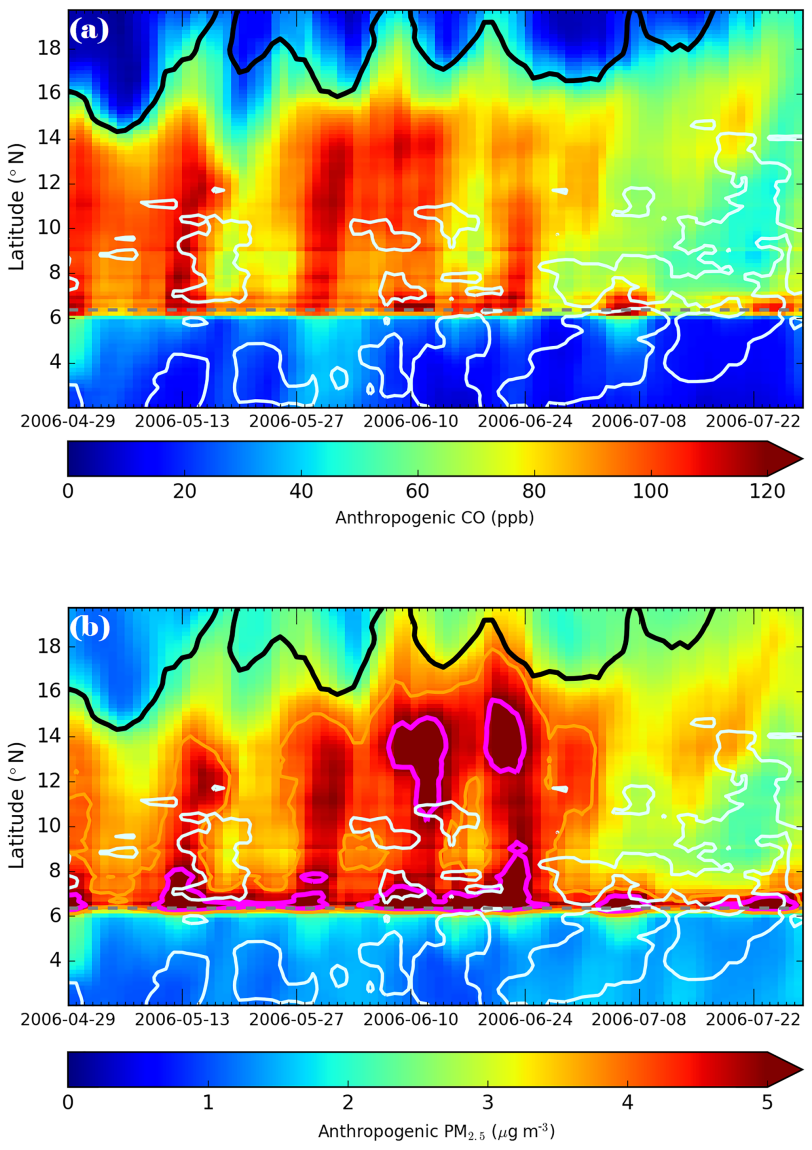

Figure 5. Time-latitude average (Hovmöller diagram) of (a) surface $\mathrm{CO}$ concentration (ppb) and (b) $\mathrm{PM}_{2.5}\left(\mu \mathrm{g} \mathrm{m}^{-3}\right)$ due to anthropogenic emissions along a meridional transect from 2 to $19^{\circ} \mathrm{N}$ and averaged from 2 to $3^{\circ} \mathrm{E}$ including Cotonou (Benin) and $\mathrm{Ni}-$ amey (Niger). Day-to-day variability is smoothed by applying a moving average of \pm 2 days. White contours are precipitation of $10 \mathrm{~mm} \mathrm{day}^{-1}$. Specific isocontours are highlighted: $4 \mu \mathrm{g} \mathrm{m}^{-3}$ (orange) and $5 \mu \mathrm{g} \mathrm{m}^{-3}$ (violet). The black line is the ITD defined as RH isocontour of $20 \%$.

tion concentration is not always associated with precipitation events. Results are presented in the same way using Hovmöller diagrams (Fig. 6). For each figure, colored isocontours are superimposed corresponding to surface anth- $\mathrm{PM}_{2.5}$ of 4 and $5 \mu \mathrm{g} \mathrm{m}^{-3}$.

For the surface wind speed, the lowest values are modeled along the coast during the whole period. The wind speed variability is weak from the coast to the Sahel. Periods of low wind speed are coincident with the highest values of surface anth-PM $\mathrm{PM}_{2.5}$. At the end of the period, when precipitation occurs inland and anth- $\mathrm{PM}_{2.5}$ is low, the meteorological situation changes suddenly over the ocean, showing the cold tongue arrival located at the Equator, which is associated with increased wind speed between the Equator and the coast, as detailed by Meynadier et al. (2016). 

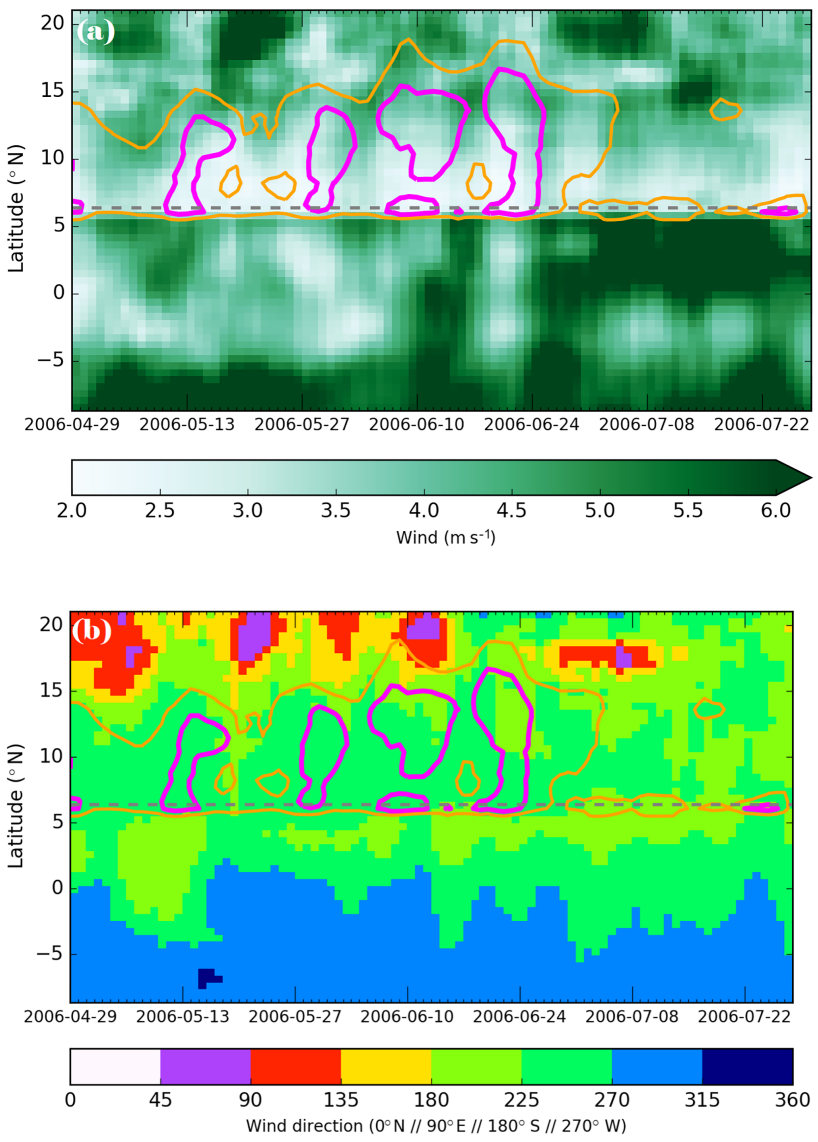

Figure 6. Time-latitude average (Hovmöller diagram) of surface wind: (a) speed and (b) direction, along a meridional transect from 2 to $19^{\circ} \mathrm{N}$ and averaged from 2 to $3^{\circ} \mathrm{E}$ including Cotonou (Benin) and Niamey (Niger). Wind directions are presented with steps of $45^{\circ}$. Day-to-day variability is smoothed by applying a moving average of \pm 2 days. Orange and violet contours are surface $\mathrm{PM}_{2.5}$ concentrations of 4 and $5 \mu \mathrm{g} \mathrm{m}^{-3}$.

Regarding the precipitation occurrences discussed in the previous section, the high surface anth- $\mathrm{PM}_{2.5}$ concentrations modeled around $\phi=12^{\circ} \mathrm{N}$ are due to a combination of low wind speed and low precipitation rates. These meteorological conditions are representative of stagnation, which accumulate pollutants in the lowest layers of the troposphere.

For the surface wind direction, the main wind direction near the coast is the southwest quarter during the whole period. There is no obvious link between wind direction changes and $\mathrm{PM}_{2.5}$ highest values over the Cotonou-Niamey meridional transect.

The large-scale variability of meteorological variables (precipitation and wind speed) controls the period of high anthropogenic pollution from the coast to the Sahel. However, it does not explain whether the high concentration over the Sahel are linked with local emissions and/or with pollutants transport from the coast.

\subsection{Monthly mean vertical structure}

\subsubsection{Anthropogenic pollution}

We now focus on the vertical structure of the lower troposphere from the surface to $4 \mathrm{~km}$ altitude in order to understand the causes of the high anth-PM $\mathrm{PM}_{2.5}$ concentration over the Sahel. Monthly averages of anth-PM ${ }_{2.5}$ concentration are analyzed together with wind circulation (monthly averages correspond to consistent meteorological periods; see Sect. 3.1). In Fig. 7, the modeled concentrations are spatially averaged over the Cotonou-Niamey meridional transect. Three isocontours $\left(3,4\right.$ and $\left.5 \mu \mathrm{g} \mathrm{m}^{-3}\right)$ are used to follow the anthropogenic pollution patterns. Results are presented at 00:00 UTC, when the NLLJ is well established (during the day, the pollution is more mixed in the PBL).

For the 3 months, the meridional wind is lower at the surface than in the boundary layer from the coast to $\sim 9^{\circ} \mathrm{N}$, highlighting the well established NLLJ. Above the northward monsoon flux, there is the SAL associated with southward winds. The highest southward wind speed in the core of the SAL between 11 and $16^{\circ} \mathrm{N}$ in latitude and 2 to $4.5 \mathrm{~km}$ altitude is the African easterly jet (AEJ).

Regarding the wind, two atmospheric cells are modeled during the 3 months (Fig. 7). There is a large cell going northward at the surface within the monsoon flow, and going backward toward the south with the SAL (or AEJ), located at $\sim 2 \mathrm{~km}$ altitude, between the coast and $\sim 16^{\circ} \mathrm{N}$. There is also a small cell turning in the same direction (counterclockwise) at $\sim 2 \mathrm{~km}$ altitude, with the downdraft at $6^{\circ} \mathrm{N}$ and the updraft at $7^{\circ} \mathrm{N}$. In May and June, the small cell is included in the large cell, while in July they are disconnected.

Regarding anth- $\mathrm{PM}_{2.5}$ concentration, these two atmospheric cells seem to interact with the anthropogenic pollution because the anth- $\mathrm{PM}_{2.5}$ isocontours shape appear to be driven by the wind patterns. The large atmospheric cell induces a recirculation of the modeled anthropogenic plume, ranging from $\phi=6$ to $18^{\circ} \mathrm{N}$ in latitude and 0.5 to $3 \mathrm{~km}$ altitude (anth- $\mathrm{PM}_{2.5}$ isocontour of $3 \mu \mathrm{g} \mathrm{m}^{-3}$ ). The center of this cell is located at $\phi \approx 14^{\circ} \mathrm{N}$ during the 3 months studied. In May, an important part of the pollution from the coast is transported at altitude within the NLLJ above the PBL (displayed by the anth-PM 2.5 isocontour of $4 \mu \mathrm{g} \mathrm{m}^{-3}$ ). In June, there is high concentration at altitude over the Sahel (displayed by the anth- $\mathrm{PM}_{2.5}$ isocontour of $5 \mu \mathrm{g} \mathrm{m}^{-3}$ ), which suggests that the atmospheric cell concentrates pollutants. Note that in July, high anth-PM 2.5 concentrations are only modeled along the coast and close to the surface.

Air masses transport anthropogenic pollutants from the coast to the Sahel. High surface concentrations of anth- $\mathrm{PM}_{2.5}$ are modeled at the latitude of the coastal urbanized areas $\left(\phi=6.3^{\circ} \mathrm{N}\right)$, leading to a plume to the north within the NLLJ and concentrating pollutants over the Sahel. 


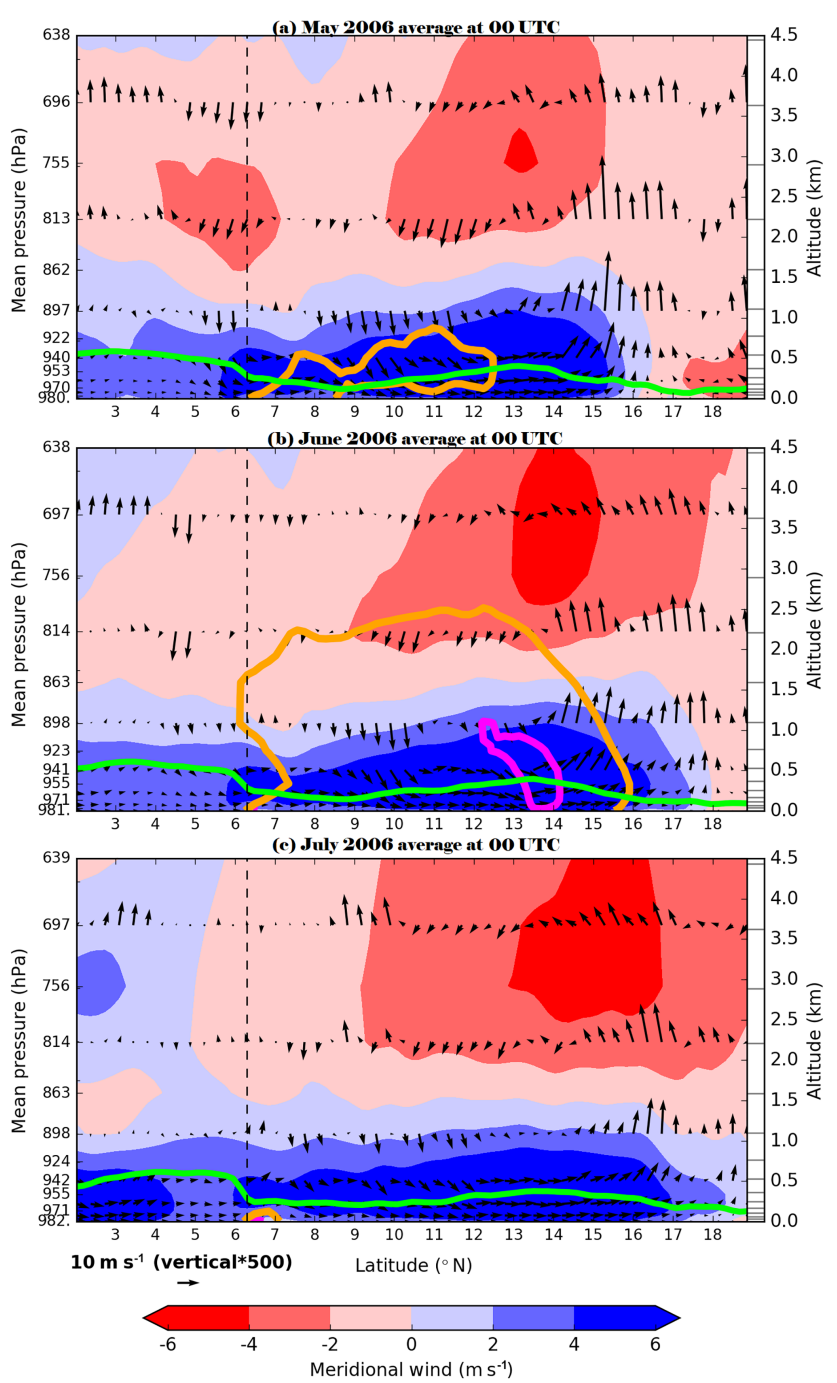

Figure 7. Vertical cross section of the meridional wind (shading in $\mathrm{m} \mathrm{s}^{-1}$ ) mean over (a) May, (b) June and (c) July, at 00:00 UTC along a meridional transect from 2 to $19^{\circ} \mathrm{N}$ and averaged from 2 to $3^{\circ} \mathrm{E}$ including Cotonou (Benin) and Niamey (Niger). Orange and violet shading represents anthropogenic $\mathrm{PM}_{2.5}$ concentrations of $=4.0 \mu \mathrm{g} \mathrm{m}^{-3}$ and $=5.0 \mu \mathrm{g} \mathrm{m}^{-3}$. Vectors represent the wind field in the plan of the transect (with an aspect ratio of 500 between the meridional and the vertical components). The green line is the PBL height (m). The gray vertical dash line is the latitude of the coast.

\subsubsection{Coastal versus Sahelian pollutant meridional transport}

A tracer experiment has been set up to analyze whether the main contributors to the Sahelian maximum are emitted locally or remotely at the coast. Gaseous tracers are released at the two major cities of the meridional transect (Cotonou in Benin and Niamey in Niger). The tracer experiment uses arbitrary units (a.u.) and considers the same quantity of tracers emitted in each town. The tracers are constantly released from the 1 to 30 June. The emission altitude occurs in the
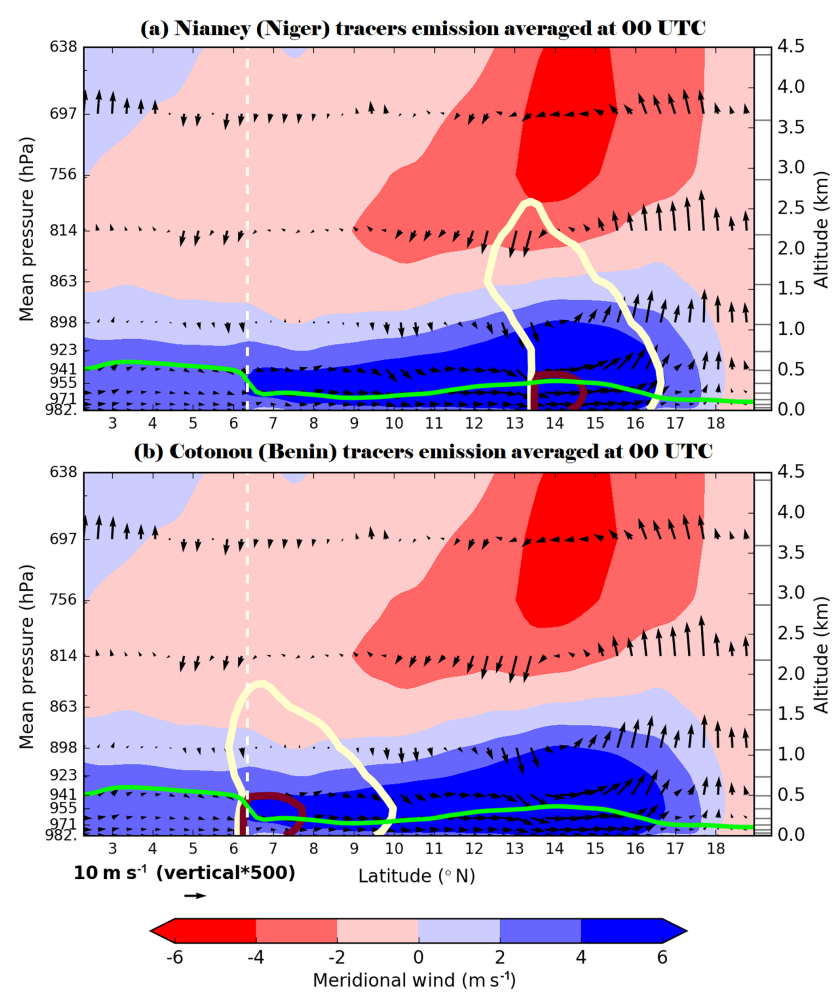

Figure 8. Vertical cross section of the meridional wind (shading in $\mathrm{m} \mathrm{s}^{-1}$ ) along a meridional transect from 2 to $19^{\circ} \mathrm{N}$, averaged from 2 to $3^{\circ} \mathrm{E}$ including Cotonou (Benin) and Niamey (Niger) and averaged over 20 to 30 June at 00:00 UTC. Isocontours represent gaseous tracer concentration continuously emitted (in arbitrary units) from the 1 to 30 June at (a) Niamey (Niger) and (b) Cotonou (Benin). Brown and yellow shading represents tracer concentration of 1 a.u. and $10 \%$ a.u., respectively. The green line is the PBL height (m). Vectors represent the wind field in the plan of the transect (with an aspect ratio of 500 between the meridional and the vertical components). The white vertical dash line is the latitude of the coast.

PBL (0-200 m) from 1 June to 30 June. Results are presented averaged during the 10 last days at 00:00 UTC as in the previous section. We consider either only coastal emissions or only Sahelian emissions in order to observe where air recirculation may concentrate the pollutants (Fig. 8).

Tracers emitted at the coast indicate that there is an important transport of coastal pollutants toward the north in the PBL. On the other hand, there is no significant transport of tracers emitted in the Sahel toward the coast. In Niamey, Cotonou tracer concentration is about $9 \%$ (of the 1 a.u. isocontour presented in Fig. 8a), while in Cotonou, Niamey tracer concentration is about $0.03 \%$ (of the 1 a.u. isocontour presented in Fig. 8b). In the HTAP anthropogenic inventories (presented in Fig. 1), the anth- $\mathrm{PM}_{2.5}$ (anth$\mathrm{CO})$ is $\sim 103(735) \mathrm{kg} \mathrm{km}^{-2} \mathrm{day}^{-1}$ in Niamey and $\sim 438$ (7707) $\mathrm{kg} \mathrm{km}^{-2} \mathrm{day}^{-1}$ in Cotonou. Therefore, an important part of the pollution over the Sahel has been emitted at the coast and it contributes to a maximum of anthropogenic pol- 


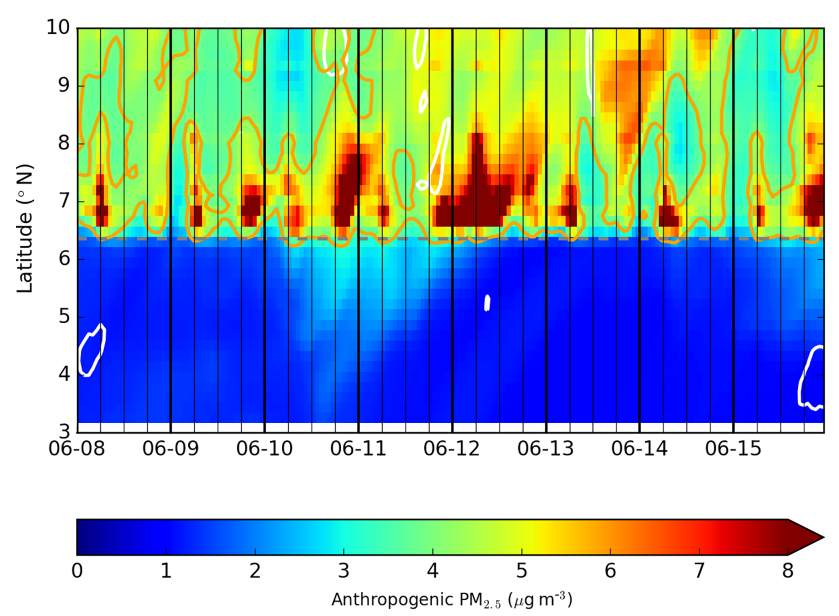

Figure 9. Time-latitude average (Hovmöller) of surface anthropogenic $\mathrm{PM}_{2.5}$ concentration $\left(\mu \mathrm{g} \mathrm{m}^{-3}\right)$ averaged along a meridional transect between 2 and $3^{\circ} \mathrm{E}$ from 1 to 17 June 2016. Black vertical bars delimit the periods of the day (00:00, 06:00, 12:00, 18:00 UTC). White isocontours present precipitation rate of $3.0 \mathrm{~mm} \mathrm{~h}^{-1}$. Orange isocontour represents the surface anthropogenic $\mathrm{PM}_{2.5}$ concentration of $4 \mu \mathrm{g} \mathrm{m}^{-3}$.

lution in June over the Sahel. In conclusion, the high concentration over the Sahel is due to the existence of a meridional atmospheric cell, which acts to accumulate pollutants emitted locally and remotely at the coast.

\section{Impact of coastal dynamics on anthropogenic pollution}

In order to better characterize coastal pollution, anth- $\mathrm{PM}_{2.5}$ for the period of 8 to 15 June 2006 is now described at hourly temporal resolution. This week includes a large variability of low to high surface concentrations.

\subsection{Surface hourly pollution variability}

The hourly surface anth- $\mathrm{PM}_{2.5}$ concentrations are shown in Fig. 9 over the Cotonou meridional transect with Hovmöller diagrams. The beginning of the week is associated with lower concentrations, as already described in Fig. 5. For most days, the highest concentrations are modeled between 18:00 and 00:00 UTC from the coast to $8^{\circ} \mathrm{N}$. This coincides with the lowest boundary layer height, which concentrates urban emissions (i.e waste burning and traffic) in a thin layer (not shown). At the coast, anth- $\mathrm{PM}_{2.5}$ concentration decreases at night (between 00:00 and 06:00 UTC) and increases again in the morning (around 06:00 UTC). This feature follows traffic emissions, which are included in the anthropogenic emission inventories. It seems that urban plumes start from the coastline at sunset (18:00 UTC) and are transported to the north in the following hours.
There is a transition from low to high concentration of anthropogenic pollution from 8 to 12 June. Anthropogenic pollution is modeled over the sea from 10 to 11 June. It is interesting to note that precipitation occurs inland on 11 June (between 18:00 and 00:00 UTC), and then high modeled concentrations persist during the night of 11-12 June. This precipitation event reflects a change in the wind patterns, which induces a change in the transport of pollutants, leading to surface concentrations up to $8 \mu \mathrm{g} \mathrm{m}^{-3}$ in Cotonou.

\subsection{Contribution of other cities at Cotonou}

At the coast, the wind direction comes from the sector S$\mathrm{SW}$, but there are diurnal variations which could affect the air pollution along the coastline. In order to distinguish pollutant transport from the different large coastal cities, a tracer experiment has been set up. The tracers are constantly released in the lowest model layers ranging from surface to $500 \mathrm{~m}$ a.s.l. (above sea level). This altitude corresponds to emission below or within the NLLJ. Three point sources have been defined: Accra in Ghana $\left(5.6^{\circ} \mathrm{N}, 0.2^{\circ} \mathrm{W}\right)$, Lome in Togo $\left(6.2^{\circ} \mathrm{N}, 1.2^{\circ} \mathrm{E}\right)$ and Cotonou in Benin $\left(6.4^{\circ} \mathrm{N}\right.$, $\left.2.4^{\circ} \mathrm{E}\right)$. The results are presented over the Cotonou meridional transect (Fig. 10). We aim at evaluating the impact of the Cotonou local emissions versus emissions from distant areas transported toward Cotonou. The emission (in arbitrary units) has the same magnitude in each city without any daily variation.

As expected, the surface concentrations of Cotonou due to local emission are only the highest at the coast. The diurnal cycle of pollutant transport appears clearly with the highest concentrations exported at the beginning of the night (18:00 UTC), when the boundary layer height decreases quickly and when the establishment of the NLLJ occurs. Up to $9^{\circ} \mathrm{N}$, high tracer concentrations are transported from Cotonou far from the point source. The Cotonou plume always transports tracers up to $7^{\circ} \mathrm{N}$; for some days, these plumes may reach the latitude of $9^{\circ} \mathrm{N}$ during the night between 18:00 and 06:00 UTC.

At Cotonou, the modeled tracer concentrations released from Lome or Accra are logically lower because the source points are not in the Cotonou meridional transect. The same kind of northward transport is observed but pollutant transport from Accra and Lome reaches Cotonou in the morning between 06:00 and 12:00 UTC for the Lome plume, and in the afternoon between 12:00 and 18:00 UTC for the Accra plume. This result is consistent with a transport speed between 10 and $20 \mathrm{~km} \mathrm{~h}^{-1}$ (the Lome-Cotonou distance is about $150 \mathrm{~km}$, and Accra-Cotonou about $300 \mathrm{~km}$ ) and synoptic wind direction from the sector SW. In arbitrary units and with the same emission at the three cities, modeled concentrations between 7 and $8^{\circ} \mathrm{N}$ are similar for the Lome and Cotonou plumes, and lower for the Accra plume. 

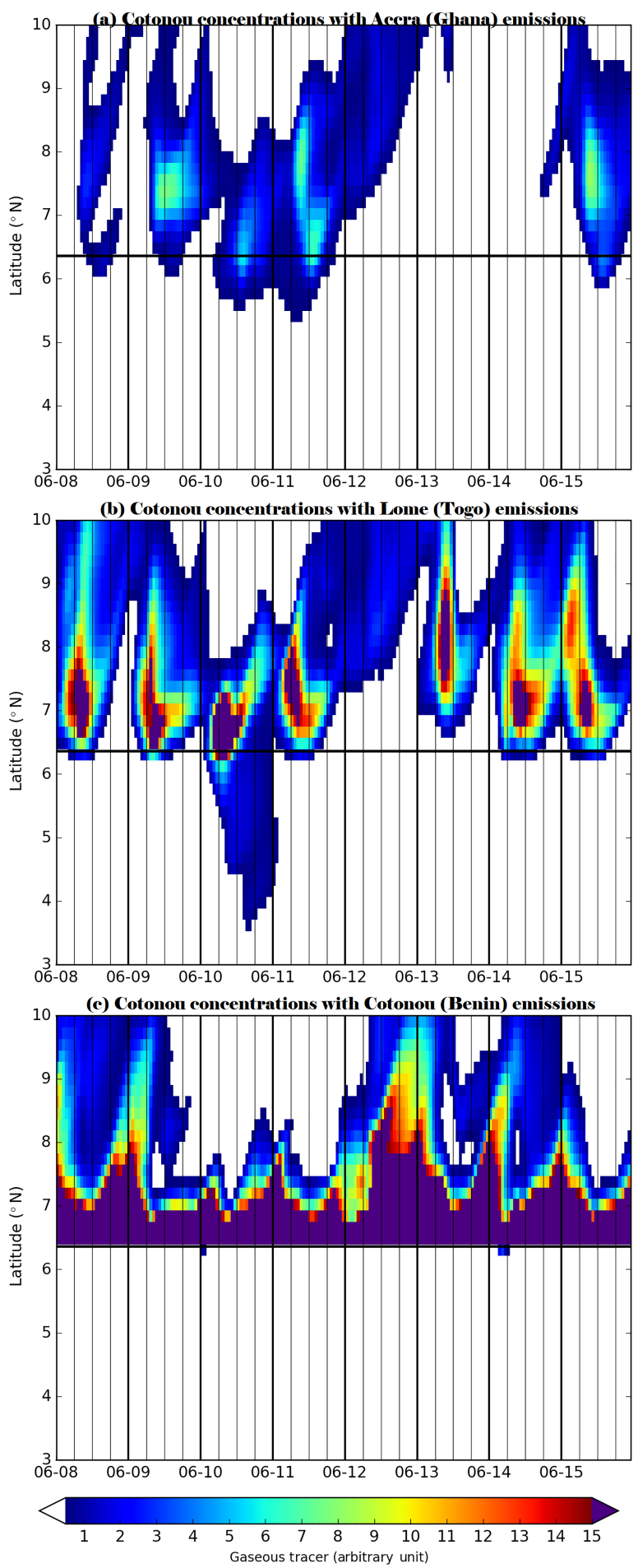

Figure 10. Time-latitude average (Hovmöller) of gaseous tracer concentration (a.u.) averaged along a meridional transect between 2 and $3^{\circ} \mathrm{E}$ centered on Cotonou (Benin) from 8 to 15 June 2006. Emissions are set up with a constant emission between 0 and $500 \mathrm{~m}$ altitude at (a) Cotonou (Benin), (b) Lome (Togo) and (c) Accra (Ghana). Black vertical bars delimit the periods of the day (00:00, 06:00, 12:00, 18:00 UTC).
The comparison between the three plumes shows a specific behavior during 10-12 June as the Cotonou pollution is not exported to the north:

- On 10 June, the Lome plume is clearly exported over the sea and very high concentrations are noticed over Cotonou. The same behavior is observed for the Accra plume with lower concentration because this location is further from Cotonou. Indeed, the Lome and Accra plumes reach Cotonou after being transported over the sea, which suggests that pollutants at the three cities have been transported eastward, leading to plumes mixing at the Cotonou location.

- On 11 June, there are still high concentrations over Cotonou due to the Accra plume probably driven by the same meteorological conditions, but it does not affect the Lome plume. This suggests a perturbation affecting Accra in particular.

- On 12 June, there is an important transport of Cotonou pollution to the north. At the same time, this is the only day when Lome and Accra plumes do not reach Cotonou, as they are shifted to the north at $7^{\circ} \mathrm{N}$ when crossing the Cotonou meridional transect.

All these results suggest a fast change of the meteorological situation, leading to air pollution. In the next section, the specificity of the vertical wind structure during this period will be studied in detail.

\section{Disturbed atmospheric dynamics and pollution transport}

In this section the analysis is refined to two periods of 2 days on 8-9 and 11-12 June 2006 in the Cotonou area. The first corresponds to non-perturbed monsoon flow situation leading to low anthropogenic pollution, while the second corresponds to a perturbed situation leading to high anthropogenic pollution.

\subsection{Evolution of the vertical structure}

In order to focus on the day/night transport from the coast to the north (described in Sect. 5.1) and the changes in dynamical regimes during this period (described in Sect. 5.2), results are presented as vertical slices in Fig. 11, averaged along the Cotonou meridional transect. The tracer concentrations, emitted separately at Lome and Cotonou, are presented as isocontours of threshold values: the emissions being arbitrary, the modeled concentrations are also arbitrary. But the same threshold is used for the two emission locations; thus, concentration magnitudes are comparable. The wind vectors (meridional/vertical components) are superimposed on the figures to highlight the vertical cells. The meridional wind is also presented as color shading for the NLLJ intensity. 

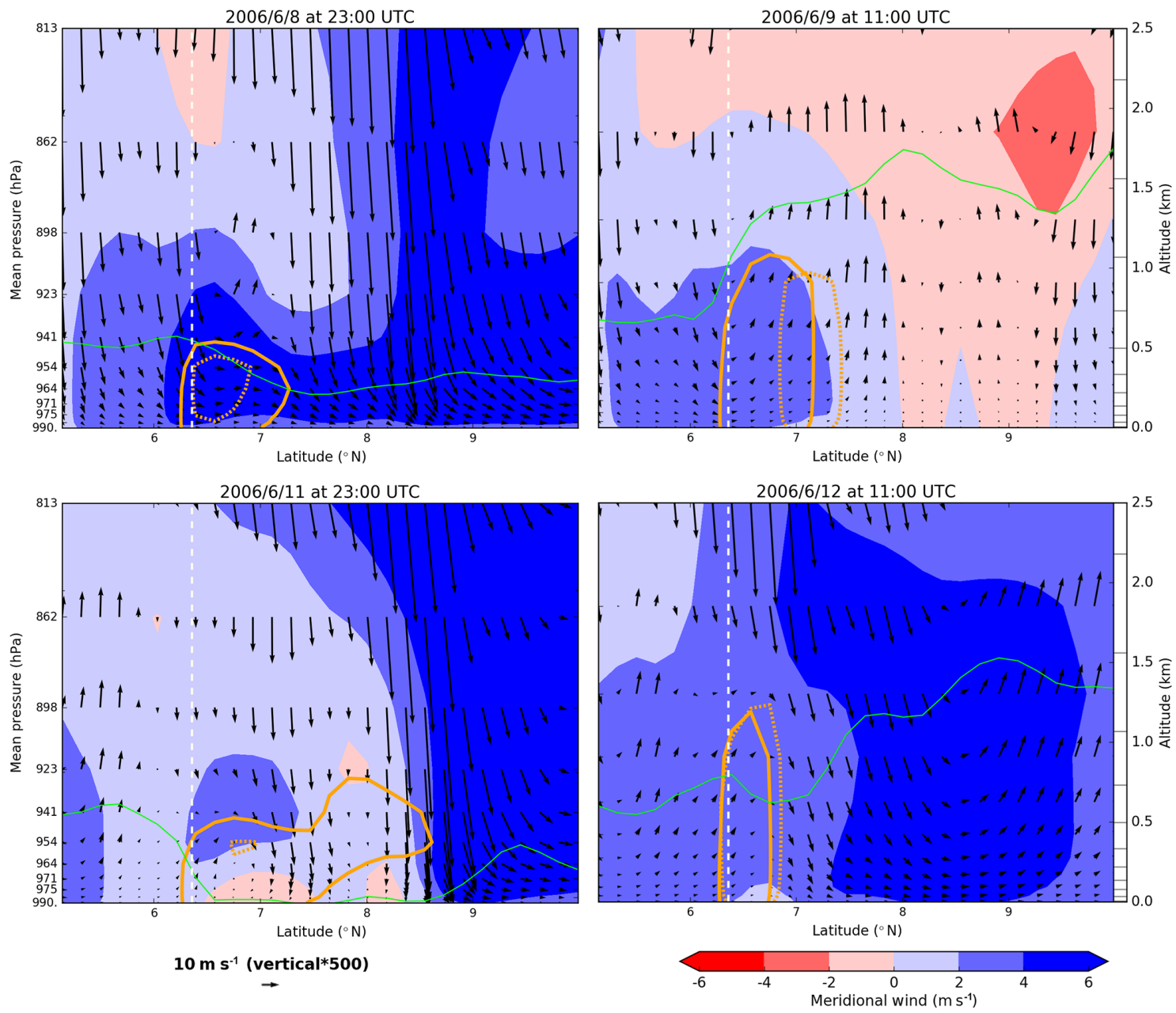

Figure 11. Vertical cross section of the meridional wind (shading in $\mathrm{m} \mathrm{s}^{-1}$ ) along a meridional transect from 5 to $10^{\circ} \mathrm{N}$ and averaged from 2 to $3^{\circ} \mathrm{E}$ including Cotonou (Benin). The two orange isocontours are tracer concentrations released in Cotonou and in Lome, respectively bold and dashed, with same threshold values (in arbitrary units). Vectors represent the wind field in the plan of the transect (with an aspect ratio of 500 between the meridional and the vertical components). The green line is the PBL height $(\mathrm{m})$. The white vertical dash line is the latitude of the coast.

The first period (8 June at 23:00 UTC and 9 June at 11:00 UTC) corresponds to a classical monsoon case, often observed and described in the literature (Abdou et al., 2010; Lothon et al., 2008). At night, surface pollutants are concentrated in a shallow layer (less than $200 \mathrm{~m}$ ), corresponding to nocturnal surface layer and to the lowest part of the NLLJ (represented by the dark blue shaded area in Fig. 11). The Cotonou and Lome plumes are mixed. During the day, the convection induces mixing in the boundary layer, which reaches $1500 \mathrm{~m}$ at 11:00 UTC over the continent. The Lome plume does not reach the coast, but it crosses the Cotonou meridional transect further to the north $\left(\sim 7^{\circ} \mathrm{N}\right)$.

On 8-9 June, an updraft-downdraft convective cell is clearly observed during the day and at night, with ascendent wind at $7^{\circ} \mathrm{N}$ and subsident wind at $6.3^{\circ} \mathrm{N}$ (the Cotonou site latitude). This circulation has already been observed for the whole studied period in Sect. 4.2.1. This is not a modeled land-sea breeze because it turns in the same direction day and night. Land-sea breezes have not been explicitly modeled because of the too coarse resolution (about $20 \mathrm{~km}$ ).

The second period (11 June at 23:00 UTC and 12 June at 11:00 UTC) corresponds to a disturbed case compared to what is usually observed in this region and for this month. Indeed, for 11 June at 23:00 UTC, the NLLJ is not present near the coast and the wind is weak from the coast to $8^{\circ} \mathrm{N}$. The modeled nocturnal PBL height is very low (less than $50 \mathrm{~m}$ ). The Lome plume is not present over Cotonou. On 12 June at 11:00 UTC, air subsidence is modeled from 7 to $10^{\circ} \mathrm{N}$. The isocontours of concentrations due to emissions in Lome and Cotonou are at the same latitude, corresponding to an isolatitudinal transport, along the coast. Compared to 8-9 June, there is no coastal cell located over the emission region. A larger cell is modeled, with high meridional wind speed (up to $4 \mathrm{~m} \mathrm{~s}^{-1}$ ). The subsidence, located at $\phi>7^{\circ} \mathrm{N}$, imports 


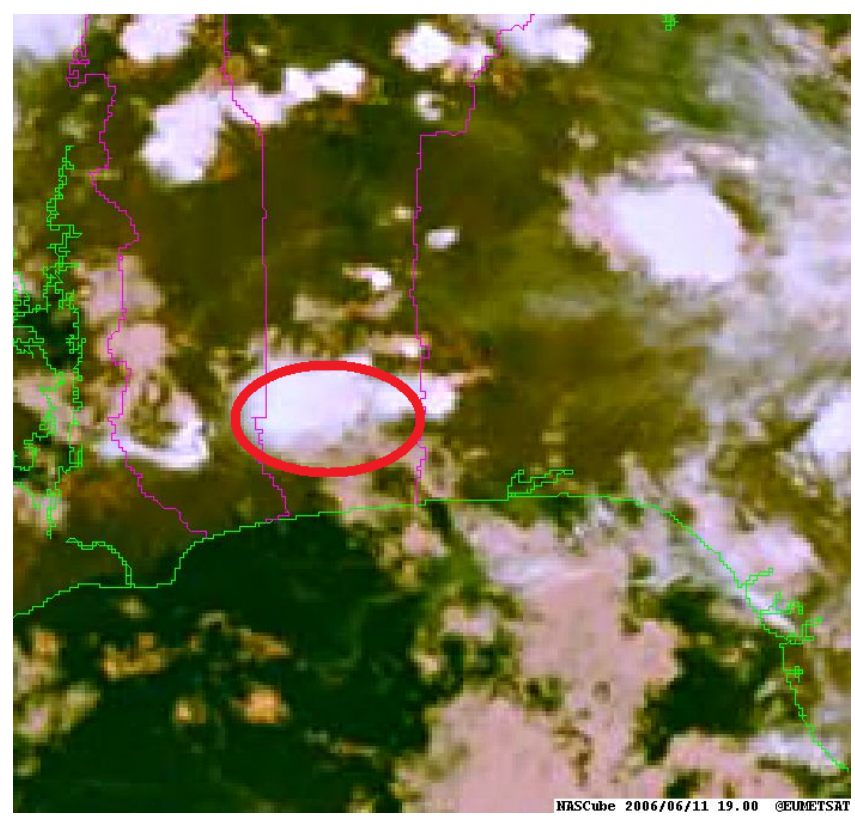

Figure 12. EUMETSAT visible image of the Cotonou area of the 11 June 2006 at 19:00 UTC (from NAScube http://nascube. univ-lille1.fr). The red ellipse is the convective cell location.

upper air masses from the free troposphere and blocks the northward transport of the coastal pollutants.

\subsection{Specificity of 11-12 June 2006}

In this last analysis, we focus on 11-12 June to understand which meteorological conditions have led to an important modeled anthropogenic $\mathrm{PM}_{2.5}$ event at Cotonou. Schwendike et al. (2010) have shown that a large MCS has occurred over Ghana due to convective instabilities at the border of Togo, Ghana and Burkina Faso. Some spots of convection ("popcorn" convection) over a large region including Cotonou have been identified on 11 June. An isolated convective cell lasting a few hours coming from southeast and moving northwest has crossed the coastline over Cotonou at around 18:00 UTC (Fig. 12), which is well in agreement with the modeled location (Fig. 13). When precipitation is inland between 19:00 and 23:00 UTC, the wind speed is zero over the coast because the monsoon flux is blocked (Fig. 13a). During these specific meteorological conditions, the high anth-PM $\mathrm{PM}_{2.5}$ surface concentrations are thus due to an accumulation of pollution over a few hours (from 19:00 to 23:00 UTC).

The same tracer experiment as described in Sect. 5.2 is used to confirm the accumulation of pollutants and to distinguish plumes of the different cities. Gaseous tracers are released with the same emission at four cities: Accra (Ghana), Lome (Togo), Cotonou (Benin) and Lagos in Nigeria have been added $\left(6.5^{\circ} \mathrm{N}, 3.4^{\circ} \mathrm{E}\right)$.
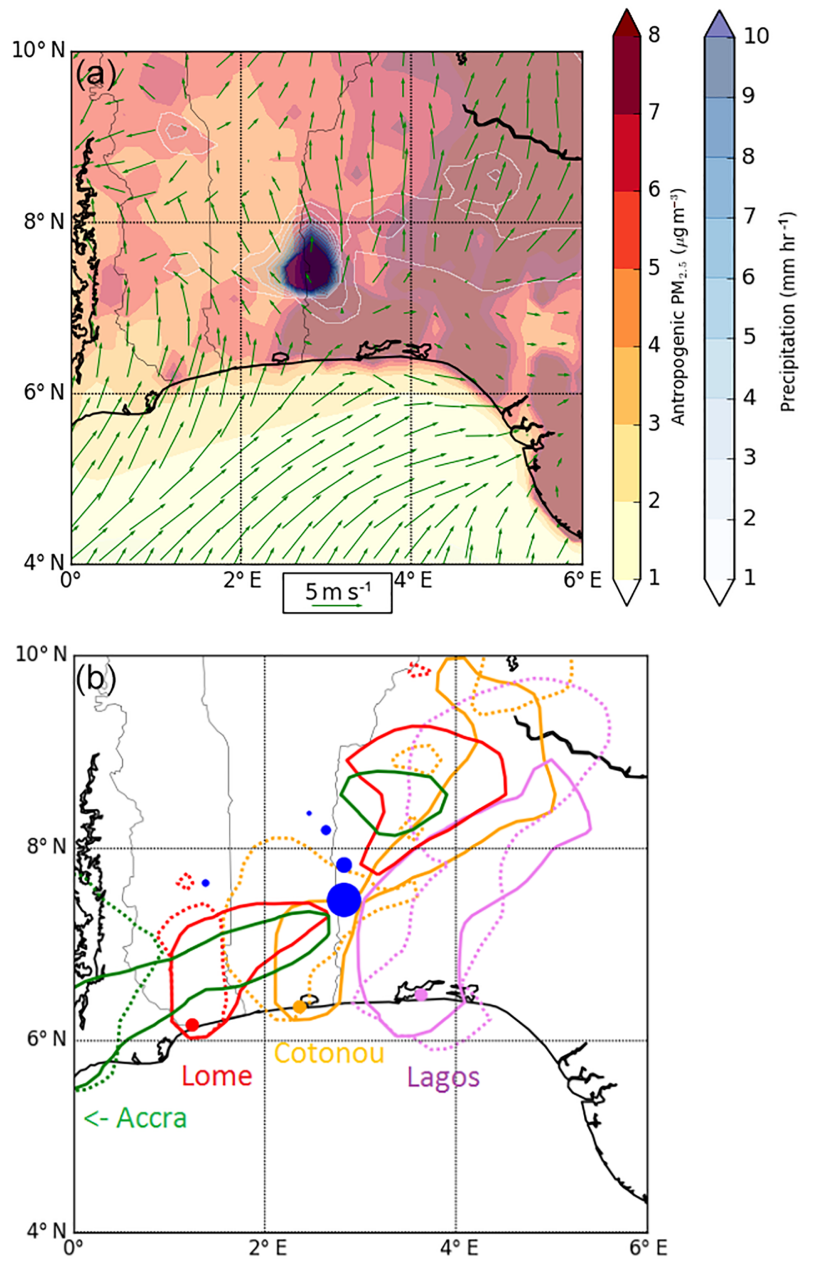

Figure 13. (a) Map of Cotonou area for the 11 June 2006 at 19:00 UTC with wind vectors at $10 \mathrm{~m}$ (green arrows), precipitation (blue shading), and anthropogenic $\mathrm{PM}_{2.5}$ concentration (red shading); (b) isocontours of tracer concentration on 11 June at 19:00 UTC (solid line) and on 12 June at 01:00 UTC (dashed line), released in Accra (Ghana) in green, Lome (Togo) in red, Cotonou (Benin) in orange, and Lagos (Nigeria) in violet. Blue dots show precipitation location each hour between 11 June at 19:00 UTC and 12 June at 01:00 UTC (the size of blue dots depends on precipitation amount).

We can notice that the pollution emitted at the different cities west from Cotonou is mixed at $\phi=7^{\circ} \mathrm{N}$ on 11 June at 19:00 UTC (Fig. 13b). Six hours later, only the Cotonou plumes is responsible for the high anth- $\mathrm{PM}_{2.5}$, which confirms pollutants accumulation because it has been blocked by the downdraft of the precipitation system over $6 \mathrm{~h}$.

This result demonstrates that during the monsoon period, specific meteorological conditions could lead to high pollution in the large Guinean coast cities, although most of the time pollution emitted along the coastline is quickly transported to the north. 


\section{Conclusions}

West African pollution was studied using both models and observations during May, June and July 2006. This corresponds to the beginning of the West African monsoon and includes the AMMA campaign observational period. The focus was on urbanized areas located along the Guinean Gulf coast and known as large gas and aerosol emitters. In addition to these anthropogenic emissions, the coast is often under the influence of long-range transport of mineral dust and biomass burning emissions. The analyses are performed for $\mathrm{CO}$ and $\mathrm{PM}_{2.5}$ over a large domain to include all sources: Central Africa for biomass burning, Sahel and Sahara for mineral dust, and a large part of the Guinea Gulf for sea salt.

The first analysis was devoted to estimating the relative contribution of each source during the 3 months in Cotonou (Benin), Djougou (Benin) and Niamey (Niger). It was shown that the surface concentrations of $\mathrm{PM}_{2.5}$ constantly increase during the period. The mineral dust relative contribution remains low close to the coast, showing that, on monthly average, pollution during this period is not dominated by mineral dust transport events. On the other hand, the biomass burning emissions increase from May to July. The anthropogenic part is stable during the whole period for the three studied sites at $\sim 50 \%$ for $\mathrm{CO}$ and $\sim 15 \%$ for $\mathrm{PM}_{2.5}$.

The second part of the study analyzed the anthropogenic contribution to $\mathrm{CO}$ and $\mathrm{PM}_{2.5}$ along a Cotonou-Niamey meridional transect. These pollutants are transported from the coast to the north as far as the Sahel $\left(13^{\circ} \mathrm{N}\right)$. The northward limit of the transport corresponds to the Intertropical Discontinuity. It was also shown that there are alternating periods of high and low concentration from Cotonou to Niamey with a weekly frequency. To understand this variability, meteorological variables were investigated. The highest surface pollutants concentrations occurred when there is no precipitation and low wind speed.

In order to better understand the meridional transport and the occurrence of high pollutant concentrations over the Sahel $\left(\sim 13^{\circ} \mathrm{N}\right)$, monthly averages of vertical wind structure were analyzed. From May to June, a large atmospheric cell going from the coast to the Sahel remains present, and it has been identified as responsible for pollutant accumulation over the Sahel emitted locally and remotely at the coast.

Focus was put on coastal dynamics and pollution transport during a restricted period, from 8 to 15 June 2006, which included high and low concentrations of anthropogenic pollution. To isolate the coastal dynamics impacts on several city plumes along the coastline, a tracer experiment was designed with emissions at Accra (Ghana), Lome (Togo) and Cotonou (Benin). The tracer concentrations confirm that, in Cotonou, the modeled concentrations are due to both local and remote emissions. A meridional transport of the anthropogenic pollution from the coast to the north has been highlighted at night linked with the nocturnal low-level jet close to the coast.
Finally, two contrasting anthropogenic pollution situations were analyzed in detail. The first situation (8-9 June) corresponds to low anthropogenic pollution during a "typical" case of monsoon dynamics, while the second situation (1112 June) corresponds to a disturbed meteorological situation due to a convective system. During 11-12 June, air subsidence is modeled at latitude $7^{\circ} \mathrm{N}$, which imports upper air masses from the free troposphere, limiting the northward transport of the coastal pollutants.

Concerning air quality and climate policy development, we showed that the export of anthropogenic pollutant from the Guinean coast toward the north could lead to cross boundary pollution plumes. This result will be confirmed by comparison to the 2016 DACCIWA campaign observations in order to propose a strategy to reduce atmospheric pollution in West Africa.

Data availability. The data used in this article are available at http: //baobab.sedoo.fr/AMMA/ (Borbon, 2006).

Competing interests. The authors declare that they have no conflict of interest.

Special issue statement. This article is part of the special issue "Results of the project 'Dynamics-aerosol-chemistry-cloud interactions in West Africa' (DACCIWA) (ACP/AMT inter-journal SI)". It is not associated with a conference.

Acknowledgements. The research leading to these results has received funding from the European Union 7th Framework Programme (FP7/2007-2013) under grant agreement no. 603502 (EU project DACCIWA: Dynamics-aerosol-chemistry-cloud interactions in West Africa). This work has been supported by the African Monsoon Multidisciplinary Analysis (AMMA) project. Based on a French initiative, AMMA was created by an international scientific group and is currently funded by a large number of agencies, especially from France, the UK, the USA and various African countries. The authors wish to thank the SAFIRE (Service des Avions Francais Instruments pour la Recherche en Environnement) for preparing and delivering the research aircraft (ATR-42). We thank Philippe Goloub and Didier Tanre for their effort in establishing and maintaining AERONET sites in Djougou (Benin) and Banizoumbou (Niger).

Edited by: Mathew Evans

Reviewed by: two anonymous referees 


\section{References}

Abdou, K., Parker, D. J., Brooks, B., Kalthoff, N., and Lebel, T.: The diurnal cycle of lower boundary-layer wind in the West African Monsoon, Q. J. Roy. Meteor. Soc., 136, 66-76, https://doi.org/10.1002/qj.536, 2010.

Akeredolu, F.: Atmospheric environment problems in Nigeria. An overview, Atmos. Environ., 23, 783-792, 1989.

Ancellet, G., Orlandi, E., Real, E., Law, K. S., Schlager, H., Fierli, F., Nielsen, J. K., Thouret, V., and Mari, C.: Tropospheric ozone production related to West African city emissions during the 2006 wet season AMMA campaign, Atmos. Chem. Phys., 11, 6349-6366, https://doi.org/10.5194/acp-11-6349-2011, 2011.

Assamoi, E.-M. and Liousse, C.: A new inventory for two-wheel vehicle emissions in West Africa for 2002, Atmos. Environ., 44, 3985-3996, https://doi.org/10.1016/j.atmosenv.2010.06.048, 2010.

Asuoha, A. N. and Osu, C. I.: Seasonal variation of meteorological factors on air parameters and the impact of gas flaring on air quality of some cities in Niger Delta (Ibeno and its environs), African Journal of Environmental Science and Technology, 9, 218-227, https://doi.org/10.5897/AJEST2015.1867, 2015.

Baklanov, A., Molina, L. T., and Gauss, M.: Megacities, air quality and climate, Atmos. Environ., 126, 235-249, https://doi.org/10.1016/j.atmosenv.2015.11.059, 2016.

Baumbach, G., Vogt, U., Hein, K. R. G., Oluwole, A. F., Ogunsola, O. J., Olaniyi, H. B., and Akeredolu, F. A.: Air pollution in a large tropical city with a high traffic density - Results of measurements in Lagos, Nigeria, Sci. Total Environ., 169, 2531, https://doi.org/10.1016/0048-9697(95)04629-F, 1995.

Bessagnet, B., Hodzic, A., Vautard, R., Beekmann, M., Cheinet, S., Honoré, C., Liousse, C., and Rouil, L.: Aerosol modeling with CHIMERE - Preliminary evaluation at the continental scale, Atmos. Environ., 38, 2803-2817, https://doi.org/10.1016/j.atmosenv.2004.02.034, 2004.

Bessagnet, B., Seigneur, C., and Menut, L.: Impact of dry deposition of semi-volatile organic compounds on secondary organic aerosols, Atmos. Environ., 44, 1781-1787, https://doi.org/10.1016/j.atmosenv.2010.01.027, 2010.

Boman, J., Lindén, J., Thorsson, S., Holmer, B., and Eliasson, I.: A tentative study of urban and suburban fine particles (PM2.5) collected in Ouagadougou, Burkina Faso, X-Ray Spectrometry, 38, 354-362, https://doi.org/10.1002/xrs.1173, 2009.

Borbon, A.: LISA - Laboratoire Inter-universitaire des Systémes Atmosphériques, AS.ATR42-Chimie - Airborne chemistry measurements, available at: http://baobab.sedoo.fr/Data-Search/ ?datsId=1270\&project_name=AMMA (last access: 12 January 2018), 2006.

Capes, G., Murphy, J. G., Reeves, C. E., McQuaid, J. B., Hamilton, J. F., Hopkins, J. R., Crosier, J., Williams, P. I., and Coe, H.: Secondary organic aerosol from biogenic VOCs over West Africa during AMMA, Atmos. Chem. Phys., 9, 3841-3850, https://doi.org/10.5194/acp-9-3841-2009, 2009.

Crétat, J. and Pohl, B.: How Physical Parameterizations Can Modulate Internal Variability in a Regional Climate Model, 69, 714724, https://doi.org/10.1175/JAS-D-11-0109.1, 2012.

Crumeyrolle, S., Tulet, P., Gomes, L., Garcia-Carreras, L., Flamant, C., Parker, D. J., Matsuki, A., Formenti, P., and Schwarzenboeck, A.: Transport of dust particles from the Bodélé region to the monsoon layer - AMMA case study of the 9-14 June 2006 period,
Atmos. Chem. Phys., 11, 479-494, https://doi.org/10.5194/acp11-479-2011, 2011.

Cuesta, J., Marsham, J. H., Parker, D. J., and Flamant, C.: Dynamical mechanisms controlling the vertical redistribution of dust and the thermodynamic structure of the West Saharan atmospheric boundary layer during summer, Atmos. Sci. Lett., 10, 34-42, https://doi.org/10.1002/asl.207, 2009.

de Coëtlogon, G., Leduc-Leballeur, M., Meynadier, R., Bastin, S., Diakhaté, M., Eymard, L., Giordani, H., Janicot, S., and Lazar, A.: Atmospheric response to sea-surface temperature in the eastern equatorial Atlantic at quasi-biweekly time-scales, Q. J. Roy. Meteor. Soc., 140, 1700-1714, https://doi.org/10.1002/qj.2250, 2014.

Dionisio, K. L., Rooney, M. S., Arku, R. E., Friedman, A. B., Hughes, A. F., Vallarino, J., Agyei-Mensah, S., Spengler, J. D., and Ezzati, M.: Within-Neighborhood Patterns and Sources of Particle Pollution: Mobile Monitoring and Geographic Information System Analysis in Four Communities in Accra, Ghana, Environ. Health Persp., 118, 607-613, https://doi.org/10.1289/ehp.0901365, 2010.

Ek, M. B., Mitchell, K. E., Lin, Y., Rogers, E., Grunmann, P., Koren, V., Gayno, G., and Tarpley, J. D.: Implementation of Noah land surface model advances in the National Centers for Environmental Prediction operational mesoscale Eta model, J. Geophys. Res.-Atmos., 108, 8851, https://doi.org/10.1029/2002JD003296, 2003.

Flamant, C., Chaboureau, J. P., Parker, D. J., Taylor, C. M., Cammas, J. P., Bock, O., Timouk, F., and Pelon, J.: Airborne observations of the impact of a convective system on the planetary boundary layer thermodynamics and aerosol distribution in the inter-tropical discontinuity region of the West African Monsoon, Q. J. Roy. Meteor. Soc., 133, 1175-1189, https://doi.org/10.1002/qj.97, 2007.

Flamant, C., Lavaysse, C., Todd, M. C., Chaboureau, J. P., and Pelon, J.: Multl-platform observations of a springtime case of Bodele and Sudan dust emission, transport and scavenging over West Africa, Q. J. Roy. Meteor. Soc., 135, 413-430, https://doi.org/10.1002/qj.376, 2009.

Flaounas, E., Bastin, S., and Janicot, S.: Regional climate modelling of the 2006 West African monsoon: sensitivity to convection and planetary boundary layer parameterisation using WRF, Clim. Dynam., 36, 1083-1105, https://doi.org/10.1007/s00382010-0785-3, 2010.

Flaounas, E., Janicot, S., Bastin, S., and Roca, R.: The West African monsoon onset in 2006: sensitivity to surface albedo, orography, SST and synoptic scale dry-air intrusions using WRF, Clim. Dynam., 38, 685-708, https://doi.org/10.1007/s00382-011-1255-2, 2011.

Folberth, G. A., Hauglustaine, D. A., Lathière, J., and Brocheton, F.: Interactive chemistry in the Laboratoire de Météorologie Dynamique general circulation model: model description and impact analysis of biogenic hydrocarbons on tropospheric chemistry, Atmos. Chem. Phys., 6, 2273-2319, https://doi.org/10.5194/acp-6-2273-2006, 2006.

Giglio, L., Csiszar, I., and Justice, C. O.: Global distribution and seasonality of active fires as observed with the Terra and Aqua Moderate Resolution Imaging Spectroradiometer (MODIS) sensors, J. Geophys. Res.-Biogeo., 111, 1-12, https://doi.org/10.1029/2005JG000142, 2006. 
Guenther, A., Karl, T., Harley, P., Wiedinmyer, C., Palmer, P. I., and Geron, C.: Estimates of global terrestrial isoprene emissions using MEGAN (Model of Emissions of Gases and Aerosols from Nature), Atmos. Chem. Phys., 6, 3181-3210, https://doi.org/10.5194/acp-6-3181-2006, 2006.

Hadji, E., Doumbia, T., Liousse, C., Galy-lacaux, C., Ababacar, S., Diop, B., Ouafo, M., Michel, E., Gardrat, E., Castera, P., Rosset, R., Akpo, A., and Sigha, L.: Real time black carbon measurements in West and Central Africa urban sites, Atmos. Environ., 54, 529-537, https://doi.org/10.1016/j.atmosenv.2012.02.005, 2012.

Hall, N. and Peyrillé, P.: Dynamics of the West African monsoon, J. Phys. IV, 139, 81-99, https://doi.org/10.1051/jp4:2006139007, 2006.

Haywood, J. M., Pelon, J., Formenti, P., Bharmal, N., Brooks, M., Capes, G., Chazette, P., Chou, C., Christopher, S., Coe, H., Cuesta, J., Derimian, Y., Desboeufs, K., Greed, G., Harrison, M., Heese, B., Highwood, E. J., Johnson, B., Mallet, M., Marticorena, B., Marsham, J., Milton, S., Myhre, G., Osborne, S. R., Parker, D. J., Rajot, J. L., Schulz, M., Slingo, A., Tanre, D., and Tulet, P.: Overview of the Dust and Biomass-burning Experiment and African Monsoon Multidisciplinary Analysis Special Observing Period-0, J. Geophys. Res.-Atmos., 113, D00C17, https://doi.org/10.1029/2008jd010077, 2008.

Holben, B. N., Eck, T. F., Slutsker, I., Tanre, D., Buis, J. P., Setzer, A., Vermote, E., Reagan, J. A., Kaufman, Y. J., Nakajima, T., Lavenu, F., Jankowiak, I., and Smirnov, A.: AERONET - A federated instrument network and data archive for aerosol characterization, Remote Sens. Environ., 66, 1-16, https://doi.org/10.1016/s0034-4257(98)00031-5, 1998.

Hong, S. and Lim, J.: The WRF single-moment 6-class microphysics scheme (WSM6), 42, 129-151, 2006.

Hong, S.-Y., Noh, Y., and Dudhia, J.: A new vertical diffusion package with an explicit treatment of entrainment processes, Mon. Weather Rev., 134, 2318-2341, https://doi.org/10.1175/MWR3199.1, 2006.

Janicot, S., Thorncroft, C. D., Ali, A., Asencio, N., Berry, G., Bock, O., Bourles, B., Caniaux, G., Chauvin, F., Deme, A., Kergoat, L., Lafore, J.-P., Lavaysse, C., Lebel, T., Marticorena, B., Mounier, F., Nedelec, P., Redelsperger, J.-L., Ravegnani, F., Reeves, C. E., Roca, R., de Rosnay, P., Schlager, H., Sultan, B., Tomasini, M., Ulanovsky, A., and ACMAD forecasters team: Large-scale overview of the summer monsoon over West Africa during the AMMA field experiment in 2006, Ann. Geophys., 26, 25692595, https://doi.org/10.5194/angeo-26-2569-2008, 2008.

Karam, D. B., Flamant, C., Tulet, P., Chaboureau, J. P., Dabas, A., and Todd, M. C.: Estimate of Sahelian dust emissions in the intertropical discontinuity region of the West African Monsoon, J. Geophys. Res.-Atmos., 114, D13106, https://doi.org/10.1029/2008JD011444, 2009.

Knippertz, P., Coe, H., Chiu, J. C., Evans, M. J., Fink, A. H., Kalthoff, N., Liousse, C., Mari, C., Allan, R. P., Brooks, B., Danour, S., Flamant, C., Jegede, O. O., Lohou, F., and Marsham, J. H.: The DACCIWA project: Dynamics-aerosolchemistry-cloud interactions in West Africa, B. Am. Meteorol. Soc., 96, 1451-1460, https://doi.org/10.1175/BAMS-D-14$00108.1,2015$.

Lafore, J.-P., Flamant, C., Guichard, F., Parker, D. J., Bouniol, D., Fink, A. H., Giraud, V., Gosset, M., Hall, N., Höller, H., Jones,
S. C., Protat, A., Roca, R., Roux, F., Saïd, F., and Thorncroft, C. Progress in understanding of weather systems in West Africa, Atmos. Sci. Lett., 12, 7-12, https://doi.org/10.1002/asl.335, 2011.

Lavaysse, C., Flamant, C., Janicot, S., Parker, D., Lafore, J. P., Sultan, B., and Pelon, J.: Seasonal evolution of the West African heat low: a climatological perspective, Clim. Dynam., 33, 313 330, 2009.

Leduc-Leballeur, M., de Coëtlogon, G., and Eymard, L.: Air-sea interaction in the Gulf of Guinea at intraseasonal time-scales: Wind bursts and coastal precipitation in boreal spring, Q. J. Roy. Meteor. Soc., 139, 387-400, https://doi.org/10.1002/qj.1981, 2013.

Lelieveld, J., Evans, J. S., Fnais, M., Giannadaki, D., and Pozzer, A.: The contribution of outdoor air pollution sources to premature mortality on a global scale, Nature, 525, 367-371, https://doi.org/10.1038/nature15371, 2015.

Li, R., Jin, J., Wang, S.-Y., and Gillies, R. R.: Significant impacts of radiation physics in the Weather Research and Forecasting model on the precipitation and dynamics of the West African Monsoon, Clim. Dynam., 44, 1583-1594, https://doi.org/10.1007/s00382014-2294-2, 2015.

Lindén, J., Thorsson, S., and Eliasson, I.: Carbon monoxide in Ouagadougou, Burkina Faso - A comparison between urban background, roadside and in-traffic measurements, Water Air Soil Poll., 188, 345-353, https://doi.org/10.1007/s11270-007-9538-2, 2008.

Lindén, J., Boman, J., Holmer, B., Thorsson, S., and Eliasson, I.: Intra-urban air pollution in a rapidly growing Sahelian city, Environ. Int., 40, 51-62, https://doi.org/10.1016/j.envint.2011.11.005, 2012.

Liousse, C., Guillaume, B., Grégoire, J. M., Mallet, M., Galy, C., Pont, V., Akpo, A., Bedou, M., Castéra, P., Dungall, L., Gardrat, E., Granier, C., Konaré, A., Malavelle, F., Mariscal, A., Mieville, A., Rosset, R., Serça, D., Solmon, F., Tummon, F., Assamoi, E., Yoboué, V., and Van Velthoven, P.: Updated African biomass burning emission inventories in the framework of the AMMAIDAF program, with an evaluation of combustion aerosols, Atmos. Chem. Phys., 10, 9631-9646, https://doi.org/10.5194/acp10-9631-2010, 2010.

Liousse, C., Assamoi, E., Criqui, P., Granier, C., and Rosset, R.: Explosive growth in African combustion emissions from 2005 to 2030, Environ. Res. Lett., 9, 035003, https://doi.org/10.1088/1748-9326/9/3/035003, 2014.

Lothon, M., Saï, F., Lohou, F., and Campistron, B.: Observation of the Diurnal Cycle in the Low Troposphere of West Africa, Mon. Weather Rev., 136, 3477-3500, https://doi.org/10.1175/2008MWR2427.1, 2008.

Mailler, S., Menut, L., Khvorostyanov, D., Valari, M., Couvidat, F., Siour, G., Turquety, S., Briant, R., Tuccella, P., Bessagnet, B., Colette, A., Létinois, L., Markakis, K., and Meleux, F.: CHIMERE-2017: from urban to hemispheric chemistrytransport modeling, Geosci. Model Dev., 10, 2397-2423, https://doi.org/10.5194/gmd-10-2397-2017, 2017.

Marais, E., Jacob, D., Wecht, K., Lerot, C., Zhang, L., Yu, K., Kurosu, T., Chance, K., and Sauvage, B.: Anthropogenic emissions in Nigeria and implications for atmospheric ozone pollution: A view from space, Atmos. Environ., 99, 32-40, https://doi.org/10.1016/j.atmosenv.2014.09.055, 2014.

Mari, C. H., Cailley, G., Corre, L., Saunois, M., Attié, J. L., Thouret, V., and Stohl, A.: Tracing biomass burning plumes 
from the Southern Hemisphere during the AMMA 2006 wet season experiment, Atmos. Chem. Phys., 8, 3951-3961, https://doi.org/10.5194/acp-8-3951-2008, 2008.

Mari, C. H., Reeves, C. E., Law, K. S., Ancellet, G., AndrésHernández, M. D., Barret, B., Bechara, J., Borbon, A., Bouarar, I., Cairo, F., Commane, R., Delon, C., Evans, M. J., Fierli, F., Floquet, C., Galy-Lacaux, C., Heard, D. E., Homan, C. D., Ingham, T., Larsen, N., Lewis, A. C., Liousse, C., Murphy, J. G., Orlandi, E., Oram, D. E., Saunois, M., Serça, D., Stewart, D. J., Stone, D., Thouret, V., Velthoven, P. V., and Williams, J. E.: Atmospheric composition of West Africa: Highlights from the AMMA international program, Atmos. Sci. Lett., 12, 13-18, https://doi.org/10.1002/as1.289, 2011.

Marticorena, B., Chatenet, B., Rajot, J. L., Traoré, S., Coulibaly, M., Diallo, A., Koné, I., Maman, A., NDiaye, T., and Zakou, A.: Temporal variability of mineral dust concentrations over West Africa: analyses of a pluriannual monitoring from the AMMA Sahelian Dust Transect, Atmos. Chem. Phys., 10, 8899-8915, https://doi.org/10.5194/acp-10-8899-2010, 2010.

Menut, L., Chiapello, I., and Moulin, C.: Predictability of mineral dust concentrations: The African Monsoon Multidisciplinary Analysis first short observation period forecasted with CHIMERE-DUST, J. Geophys. Res.-Atmos., 114, 1-13, https://doi.org/10.1029/2008JD010523, 2009.

Menut, L., Bessagnet, B., Khvorostyanov, D., Beekmann, M., Blond, N., Colette, A., Coll, I., Curci, G., Foret, G., Hodzic, A., Mailler, S., Meleux, F., Monge, J.-L., Pison, I., Siour, G., Turquety, S., Valari, M., Vautard, R., and Vivanco, M. G.: CHIMERE 2013: a model for regional atmospheric composition modelling, Geosci. Model Dev., 6, 981-1028, https://doi.org/10.5194/gmd-6-981-2013, 2013.

Menut, L., Siour, G., Mailler, S., Couvidat, F., and Bessagnet, B.: Observations and regional modeling of aerosol optical properties, speciation and size distribution over Northern Africa and western Europe, Atmos. Chem. Phys., 16, 12961-12982, https://doi.org/10.5194/acp-16-12961-2016, 2016.

Meynadier, R., de Coëtlogon, G., Leduc-Leballeur, M., Eymard, L., and Janicot, S.: Seasonal influence of the sea surface temperature on the low atmospheric circulation and precipitation in the eastern equatorial Atlantic, Clim. Dynam., 47, 1127-1142, https://doi.org/10.1007/s00382-015-2892-7, 2016.

Minga, A., Thouret, V., Saunois, M., Delon, C., Serça, D., Mari, C., Sauvage, B., Mariscal, A., Leriche, M., and Cros, B.: What caused extreme ozone concentrations over Cotonou in December 2005?, Atmos. Chem. Phys., 10, 895-907, https://doi.org/10.5194/acp-10-895-2010, 2010.

Mlawer, E. J., Taubman, S. J., Brown, P. D., Iacono, M. J., and Clough, S. A.: Radiative transfer for inhomogeneous atmospheres: RRTM, a validated correlated-k model for the longwave, J. Geophys. Res., 102, 16663, https://doi.org/10.1029/97JD00237, 1997.

Ndoke, P. and Jimoh, O.: Impact of traffic emission on air quality in a developing city of Nigeria, Assumpt. Univ. J. Technol, 8, 222-227, 2005.

Ogunjobi, K. O., He, Z., and Simmer, C.: Spectral aerosol optical properties from AERONET Sun-photometric measurements over West Africa, Atmos. Res., 88, 89-107, https://doi.org/10.1016/j.atmosres.2007.10.004, 2008.
Parker, D. J., Burton, R. R., Diongue-Niang, A., Ellis, R. J., Felton, M., Taylor, C. M., Thorncroft, C. D., Bessemoulin, P., and Tompkins, A. M.: The diurnal cycle of the West African monsoon circulation, Q. J. Roy. Meteor. Soc., 131, 2839-2860, https://doi.org/10.1256/qj.04.52, 2005.

Péré, J., Mallet, M., Pont, V., and Bessagnet, B.: Evaluation of an aerosol optical scheme in the chemistrytransport model CHIMERE, Atmos. Environ., 44, 3688-3699, https://doi.org/10.1016/j.atmosenv.2010.06.034, 2010.

Péré, J. C., Mallet, M., Bessagnet, B., and Pont, V.: Evidence of the aerosol core-shell mixing state over Europe during the heat wave of summer 2003 by using CHIMERE simulations and AERONET inversions, Geophys. Res. Lett., 36, L09807, https://doi.org/10.1029/2009GL037334, 2009.

Pospichal, B., Karam, D., Crewell, S., Flamant, C., Hünerbein, A., Bock, O., and Saïd, F.: Diurnal cycle of the intertropical discontinuity over West Africa analysed by remote sensing and mesoscale modelling, Q. J. Roy. Meteor. Soc., 136, 92-106, https://doi.org/10.1002/qj.435, 2010.

Redelsperger, J. L., Thorncroft, C. D., Diedhiou, A., Lebel, T., Parker, D. J., and Polcher, J.: The African Monsoon Multidisciplinary Analysis: An International Research Project and Field Campaign, B. Am. Meteorol. Soc., 87, 1739-1746, 2006.

Reeves, C. E., Formenti, P., Afif, C., Ancellet, G., Attié, J.-L., Bechara, J., Borbon, A., Cairo, F., Coe, H., Crumeyrolle, S., Fierli, F., Flamant, C., Gomes, L., Hamburger, T., Jambert, C., Law, K. S., Mari, C., Jones, R. L., Matsuki, A., Mead, M. I., Methven, J., Mills, G. P., Minikin, A., Murphy, J. G., Nielsen, J. K., Oram, D. E., Parker, D. J., Richter, A., Schlager, H., Schwarzenboeck, A., and Thouret, V.: Chemical and aerosol characterisation of the troposphere over West Africa during the monsoon period as part of AMMA, Atmos. Chem. Phys., 10, 7575-7601, https://doi.org/10.5194/acp-10-7575-2010, 2010.

Sauvage, B., Thouret, V., Cammas, J.-P., Gheusi, F., Athier, G., and Nédélec, P.: Tropospheric ozone over Equatorial Africa: regional aspects from the MOZAIC data, Atmos. Chem. Phys., 5, 311335, https://doi.org/10.5194/acp-5-311-2005, 2005.

Schmechtig, C., Marticorena, B., Chatenet, B., Bergametti, G., Rajot, J. L., and Coman, A.: Simulation of the mineral dust content over Western Africa from the event to the annual scale with the CHIMERE-DUST model, Atmos. Chem. Phys., 11, 7185-7207, https://doi.org/10.5194/acp-11-7185-2011, 2011.

Schwendike, J., Kalthoff, N., and Kohler, M.: The impact of mesoscale convective systems on the surface and boundarylayer structure in West Africa: Case-studies from the AMMA campaign 2006, Q. J. Roy. Meteor. Soc., 136, 566-582, https://doi.org/10.1002/qj.599, 2010.

Skamarock, W. C. and Klemp, J. B.: A time-split nonhydrostatic atmospheric model for weather research and forecasting applications, J. Comput. Phys., 227, 3465-3485, https://doi.org/10.1016/j.jcp.2007.01.037, 2008.

Sultan, B. and Janicot, S.: Abrupt shift of the ITCZ over West Africa and intra-seasonal variability, Geophys. Res. Lett., 27, 33533356, 2000.

Sultan, B. and Janicot, S.: The West African monsoon dynamics. Part II: The "preonset" and "onset" of the summer monsoon, J. Climate, 16, 3407-3427, 2003.

Sultan, B., Janicot, S., and Diedhiou, A.: The West African Monsoon Dynamics. Part I: Documentation of Intraseasonal Vari- 
ability, J. Climate, 16, 3389-3406, https://doi.org/10.1175/15200442(2003)016<3389:TWAMDP>2.0.CO;2, 2003.

Turquety, S., Menut, L., Bessagnet, B., Anav, A., Viovy, N., Maignan, F., and Wooster, M.: APIFLAME v1.0: highresolution fire emission model and application to the EuroMediterranean region, Geosci. Model Dev., 7, 587-612, https://doi.org/10.5194/gmd-7-587-2014, 2014.

von Storch, H., Langenberg, H., and Feser, F.: A Spectral Nudging Technique for Dynamical Downscaling Purposes, Mon. Weather Rev., 128, 3664-3673, https://doi.org/10.1175/15200493(2000)128<3664:ASNTFD>2.0.CO;2, 2000.
Williams, J. E., Scheele, M. P., van Velthoven, P. F. J., Thouret, V., Saunois, M., Reeves, C. E., and Cammas, J.-P.: The influence of biomass burning and transport on tropospheric composition over the tropical Atlantic Ocean and Equatorial Africa during the West African monsoon in 2006, Atmos. Chem. Phys., 10, 9797-9817, https://doi.org/10.5194/acp-10-9797-2010, 2010.

Zhu, X. R.: GAW Report No. 205 WMO-IGAC Impacts of Megacities on Air Pollution and Climate, Tech. Rep. 205, 2012. 